\title{
The Productivity Gaps of Female-Owned Firms: Evidence from Ethiopian Census Data
}

\author{
DENNIS ESSERS \\ National Bank of Belgium and Institute of Development Policy, \\ University of Antwerp
}

KELBESA MEGERSA

Institute of Development Studies, University of Sussex

\author{
MARCO SANFILIPPO \\ University of Turin, European University Institute, \\ and Institute of Development Policy, University of Antwerp
}

\section{Introduction}

Closing gender gaps has become imperative in global development circles. While considerable progress was recorded under the Millennium Development Goals, the recently established Sustainable Development Goals call for renewed efforts to reduce gender discrimination and increase empowerment, with a stronger emphasis on the promotion of a more active role for women as decision makers and owners of economic resources. In many developing countries, including in subSaharan Africa, issues relating to the extent and nature of women's participation in productive activities, to the allocation of women over specific sectors and types of jobs, and to high gender inequalities in the labor market remain pressing (Menon and Rodgers 2009; Hallward-Driemeier 2011; Juhn, Ujhelyi, and Villegas-Sanchez 2014). Also, much is still unknown about which and how discriminatory practices and institutional constraints to which women are subjected influence their entrepreneurial capabilities.

The literature on gender, entrepreneurship, and firm performance generally shows evidence of significant gender gaps both at market entry (i.e., women

We would like to thank the editor, Marcel Fafchamps; the associate editor; two anonymous reviewers; and participants at the Third Italian Development Economists Association Conference in Florence, the 2017 Center for the Study of African Economies Annual Conference in Oxford, the International Monetary Fund Gender and Macroeconomics Conference in Washington, DC, and a seminar at the University of Florence for useful comments. We acknowledge support from the Ethiopian Economic Association for facilitating the collection of census data from the Central Statistical Agency of Ethiopia and are grateful to Keisuke Kondo for his assistance with the estquant command in Stata. The views expressed in this paper as well as any remaining errors are those of the authors only and should not be attributed to the National Bank of Belgium or the Eurosystem. Contact the corresponding author, Marco Sanfilippo, at marco.sanfilippo@uantwerp.be. 
are less likely to become entrepreneurs) as well as in several dimensions of female-owned firms' performance (Hellerstein and Neumark 1999; World Bank 2012; Marques 2015). A good part of this literature concerns industrialized rather than low-income countries and micro- and small entrepreneurs rather than larger enterprises (for a more complete overview, see Klapper and Parker 2011). The evidence for transition and developing countries is mixed (Sabarwal and Terrell 2008; Bruhn 2009), and the few cross-country studies including sub-Saharan Africa in their analysis do not observe stark gender-based firm performance differences (Bardasi, Blackden, and Guzman 2007; Bardasi, Sabarwal, and Terrell 2011). Conversely, country-specific evidence in subSaharan Africa suggests considerably lower female firm productivity in Ghana (Jones 2012) and Madagascar (Nordman and Vaillant 2014). The lack of systematic evidence may be due to the type and quality of the data used as well as to the definition of female ownership adopted (Aterido and Hallward-Driemeier 2011).

Furthermore, there is no conclusive evidence of the underlying factors explaining any gender gaps in firm performance in developing countries and sub-Saharan Africa more specifically, although several hypotheses have been advanced (for a recent survey, see Campos and Gassier 2017). In many countries, female businesses are concentrated in sectors characterized by limited economies of scale, low growth, low technology and capital, and intense competition (World Bank 2012; Kucera and Tejani 2014). Also, female entrepreneurs may be disadvantaged in terms of education, experience, and other skill-related traits that are positively linked to productivity (Aterido and Hallward-Driemeier 2011). Yet the empirical study by Nix, Gamberoni, and Heath (2016) on microenterprises based in the Republic of Congo, Ghana, Rwanda, and Tanzania shows that the gender performance gap remains partly unexplained even after controlling for industry, firm, and owners' characteristics. Similar conclusions are reached by Hardy and Kagi (2018b), who focus on the case of Ghana. The importance of adverse external conditions, including access to credit and capital, has been tested in experimental research, which finds that returns to capital grants tend to be positive for male-operated microenterprises but close to zero for women (de Mel, McKenzie, and Woodruff 2008, 2009; Fafchamps et al. 2014). ${ }^{1}$ Finally, a recent study on Ghana by Hardy and Kagi (2018a) points to the existence of demand-side constraints too. Limited formal employment

\footnotetext{
${ }^{1}$ Household capture may help explain this striking finding. Recent work by Bernhardt et al. (2017), using experimental data from India, Sri Lanka, and Ghana, shows that returns to capital in femaleoperated microenterprises receiving grants are lower in multiple-enterprise households but not in singleenterprise households. This suggests that women may be investing the capital in their husbands' enterprises rather than in their own. In line with this, Fafchamps et al. (2014) find that in Ghana the profits of female enterprises respond more positively to in-kind grants, which are less easily diverted to other purposes.
} 
opportunities for women increase the number of female microentrepreneurs, thereby generating lower market-size-to-firm ratios and higher demand scarcity for female-owned firms.

In this paper, we engage with some of the above issues and complement the empirical literature on gender-based firm productivity differences. Our overall aim is to contribute to a deeper understanding of the extent, nature, and origins of female-owned firms' productivity gaps. We believe that such an understanding is crucial if female-owned firms are to be supported in an effective and cost-efficient manner. We rely on a large panel of Ethiopian manufacturing firms based on an annual census run by Ethiopia's Central Statistical Agency over 2003-9. The case of Ethiopian manufacturing is particularly interesting and relevant for our purposes. Over the past decades, the country has experienced sustained economic growth, spurred by large infrastructural investments, waves of trade liberalization, and industrial policies supporting the growth of the manufacturing sector and the structural transformation of the economy (World Bank 2015) and aimed at fostering broader economic participation and enhancing productivity. Importantly, however, large gender gaps remain in the Ethiopian labor market. Female entrepreneurship is still limited in the country because of the existence of higher barriers for women than for men, including access to finance and education (Alibhai et al. 2017). A few previous studies that have looked into gender-based heterogeneity in firm productivity in Ethiopia based on survey data have reported a negative correlation between female business ownership and productivity, especially in rural areas (Rijkers, Söderbom, and Loening 2010; Rijkers and Costa 2012). The country performs relatively poorly on the World Economic Forum's Gender Gap Index (ranked 115 out of 144 countries in 2017) in part because of low scores on the economic participation and opportunity subindex, which considers women's labor force participation, gender wage inequality, and prevalence of women in senior professional and technical positions (World Economic Forum 2017). A report by the International Labor Organization (2015) adds that only 22\% of managers in Ethiopia are women, which puts it in the group of worst-performing countries in this specific area. That notwithstanding, other studies have found that recent policy efforts_-such as the combined reforms in the family code and in community-based land registration-have already brought measurable improvements in women's economic participation and welfare in Ethiopia (HallwardDriemeier and Gajigo 2015; Kumar and Quisumbing 2015).

The objective of our empirical analysis is twofold. First, along the lines of existing studies on the topic, we try to find out whether and to what extent female-owned firms in the Ethiopian manufacturing sector exhibit a performance gap compared with their male-owned counterparts. We do so taking total factor productivity (TFP) as our measure of firm performance. Unlike the extant 
literature on Ethiopia and other developing countries, which mostly relies on survey data and includes large numbers of small and informal firms, we base our analysis on census data (thus avoiding problems of sample representativeness) and consider the universe of formal firms in the Ethiopian manufacturing sector. This marks an important difference from existing studies looking at the gender productivity gap in Ethiopia (Rijkers, Söderbom, and Loening 2010; Rijkers and Costa 2012), given that they focus primarily on firms based in rural areas, whereas our (larger) firms tend to be based in urban areas.

Although our choice for the census data has the disadvantage of leaving out the majority of firms based in the country, which are small and informal, we are confident about the relevance of our analysis, given that the census firms represent roughly $50 \%$ and $90 \%$ of total employment and value added in the whole Ethiopian manufacturing sector, respectively. To our knowledge, we are the first to employ firm census data from a sub-Saharan Africa country for these purposes. The richness of our data set allows us to check the robustness of female-male firm productivity differences to alternative definitions of female ownership, based either on capital shares or on the number of female owners, and to control for several observable characteristics likely to affect the productivity gap when estimating regressions. Note, however, that above all, our study is of a descriptive nature. Because of the nonexperimental setup, our results should not be interpreted in a causal way.

In the second part of the paper, we look beyond average gender-based firm productivity gaps and investigate differences between the productivity distributions of male- and female-owned firms, which sheds some additional light on the potential mechanisms at work. We do this in two ways. First, we apply the Oaxaca-Blinder-type decomposition approach designed by Firpo, Fortin, and Lemieux $(2007,2009)$. This type of analysis enables us to identify how much of the productivity gap between male- and female-owned firms can be attributed to differences in observable firm characteristics/factors (what we will label as the "composition effect") and how much by different returns to those factors (the "structural effect") at different quantiles of the productivity distribution. ${ }^{2}$ Given that the experimental evidence on smaller firms seems to indicate that the gender gaps in performance are mostly explained by lower returns to observables, the evidence we provide here on larger firms complements existing knowledge on the issue well. Second, we draw on another quantilebased methodology originally developed by Combes et al. (2012). Applied to our context, the Combes et al. (2012) approach allows us to evaluate in

\footnotetext{
${ }^{2}$ Note that we follow Firpo, Fortin, and Lemieux (2007) in using the term "effect" here. Again, the data at hand do not allow us to draw causal conclusions.
} 
which ways the shape of the firm productivity distribution varies along the gender of firm owners. We formally distinguish between three transformationsthat is, shift, dilation, and truncation-in the productivity distribution of female-owned firms relative to that of male-owned firms. More specifically, we look into how much the latter distribution would need to be moved rightward along the $X$-axis (captured by the shift parameter), what constant factor each of its observations would need to be divided by (dilation), and what share of observations would need to be excluded from its left tail (truncation) in order to best approximate the former distribution.

Our regression results show a consistent productivity gap for female-owned firms. The size of the average productivity gap varies considerably, however, depending on the exact specification and definition of female ownership adopted (with stricter measures of female control over the firm resulting in larger estimated gaps). Our preferred estimation indicates that female-owned firms are, on average, about $12 \%$ less productive than male-owned firms, a result that is in line with previous survey-based findings for large formal firms in other subSaharan Africa countries (Aterido and Hallward-Driemeier 2011) but lower compared with other studies that include also smaller, informal, and rural firms (Rijkers, Söderbom, and Loening 2010; Jones 2012; Nordman and Vaillant 2014). Our analysis further shows that lower capital intensity and allocation into less productive, more labor-intensive and female worker-dominated industries are among the mechanisms explaining (part of) the female firm productivity gap.

Next, we provide new insights based on a formal comparison of female and male firm productivity distributions. Results from our application of the Firpo, Fortin, and Lemieux $(2007,2009)$ quantile decomposition suggest that a consistent part of the productivity differences for the firms populating the central section of the productivity distribution can be attributed to structural effects and mainly to differences in the returns to capital. This echoes existing research based on field experiments with capital grants (de Mel, McKenzie, and Woodruff 2008, 2009), suggesting that similar mechanisms may also be at work for more structured firms. Conversely, gender productivity gaps in the upper part of the productivity distribution tend to be related to composition effects, that is, differences in observed characteristics and especially in firm size, capital endowments, and the internationalization of firms.

Results based on the Combes et al. (2012) approach provide evidence for a significant leftward shift and significantly lower dilation of the female firm productivity distribution compared with the male distribution. Interestingly, we also uncover that a (though very small) part of the female firm productivity gap can be explained by the female firms' productivity distribution displaying 
a longer left tail. When we consider a sample confined to firms in the capital region around Addis Ababa, where more than half of all manufacturing establishments are located, the economic significance of the left shift strengthens and also the lower dilation is confirmed. Patterns become more heterogeneous once we split the sample into smaller subgroups and when accounting for sectors and/or other key observable firm characteristics.

How to reconcile these various pieces of evidence? Taken together, our results indicate that female-owned firms are not only systematically less productive but also more homogeneous in terms of productivity than male-owned firms. This homogeneity is likely the result of female firms' concentration in certain (lower-productivity) sectors and subsectors. On the one hand, as shown by our decomposition analysis, the productivity differences in the central part of the distribution remain largely unexplained by observable characteristics of the firms. Rather, they seem to be driven by differences in returns to capital, whose origins and motivations have not yet been fully identified by the existing literature (de Mel, McKenzie, and Woodruff 2008, 2009; Fafchamps et al. 2014; Bernhardt et al. 2017) and which, unfortunately, we cannot explore further with our data. On the other hand, we find that there is only a very small number of highly productive female firms that coexist with a much larger group of substantially less productive establishments. In the upper tail of the distribution, particular observable characteristics of female firms, such as relatively small size and limited capital, seem to make it harder for them to stand out. All in all, our findings suggest that various forces are at work. Policy makers bound on closing the gender-based firm productivity gap in Ethiopia will need to heed its heterogeneous nature.

The remainder of the paper is structured as follows. Section II introduces our data and methodology. We then present the regression results for the average female-male firm productivity gap in Section III, and we introduce and implement the two quantile approaches by Firpo, Fortin, and Lemieux (2007, 2009) and Combes et al. (2012) that we use to compare female and male firm productivity distributions in Section IV. Section V concludes.

\section{Data and Descriptive Analysis}

This paper uses manufacturing firm-level data from Ethiopia over the period 2003-9. Our data are sourced from the annual census of large and medium manufacturing firms run by the Central Statistical Authority, which covers all firms that engage more than 10 people and that employ electricity in their production process. ${ }^{3}$ All firms need to comply with Central Statistical Authority

\footnotetext{
${ }^{3}$ Persons engaged include both workers and unpaid working owners.
} 
requirements, and the census therefore represents the universe of more structured, formal manufacturing firms in the country. As mentioned earlier, while our census data have the limitation of excluding the largest part of Ethiopian firms, which are small and informal, it allows us to analyze a group of firms accounting for half of total employment and most of the value added created in Ethiopia's manufacturing sector. Table A1 details the industry-level shares of total firm numbers, total employment, and total value added that are represented by the census firms in 2008, based on Central Statistical Authority $(2009,2010)$ reports of the manufacturing census and of the Ethiopian Small Scale Manufacturing Industry Survey (SSIS), a representative survey of manufacturing firms with less than 10 employees. ${ }^{4}$ For 2008, the SSIS reports on over 43,000 small firms (53\% of which are grain mills), engaging about 139,000 people and generating 1.1 billion birr in value added. The 2008 census, on the other hand, counts around 1,900 firms, engaging 134,000 people and producing 9.2 billion birr of value added. ${ }^{5}$ As shown in table A1, census firms account for the lion's share of both employment and value added in nearly all manufacturing industries. Exceptions are the food industry, metal products, and furniture, industries in which smaller firms dominate in terms of employment numbers (but not value added). ${ }^{6}$

This data set, in various versions and guises, has been employed in the past to study firm growth, survival, and structural change (Bigsten and Gebreeyesus 2007; Shiferaw 2009; Söderbom 2012); the role of exporting and trade liberalization on productivity (Bigsten and Gebreeyesus 2009; Fiorini, Sanfilippo, and Sundaram 2018); returns to capital in formal versus informal firms (Siba 2015); job creation, job destruction, and skill-biased technological change (Shiferaw and Bedi 2013); and road infrastructure and firm entry (Shiferaw et al. 2015), among other topics. Importantly, however, to our knowledge, it has never been used to evaluate gender-based firm productivity differences. We believe the data set's extensive coverage of larger manufacturing enterprises and rich details on ownership structure make it particularly suitable for our purposes.

The data set includes detailed information on output, capital, labor, and other inputs for all firms. In addition, it provides precise information on the location of firms by their region, zone, district (woreda), and town of origin. It also contains

\footnotetext{
${ }^{4}$ The year 2008 is the latest for which the census and the survey were run concurrently.

${ }^{5}$ The small difference with the actual number of firms in our data set, as reported in table A2, is due to the fact that some firms did not respond to the census questions.

${ }^{6}$ Note that in the SSIS, the food industry is largely characterized by the presence of grain mills. In 2008 , they represented over $90 \%$ of total firms in that industry as well as $93 \%$ of employment and $89 \%$ of value added (Central Statistical Authority 2010).
} 
data on the industry of firms' activities, up to the four-digit level of the International Standard Industrial Classification (ISIC) revision 3.

Crucially, the census includes very granular information on the ownership structure of each firm. Constructing a good gender-based measure of ownership from firm-level data is not trivial. In fact, the definition of what constitutes a female business and the distinction between ownership and control matter a great deal in assessing productivity differences. ${ }^{7}$ Most studies have used a generic measure of female participation in the ownership of a firm, that is, a dummy that equals 1 if any woman can be found among the owners. While this perfectly fits the case of sole-owned firms, it may be a less precise measure of female ownership in firms with multiple owners, including larger ones. Some studies, however, have had the advantage of using purposely collected survey data, including specific questions related to the effective control of women in firms' decision-making process (sub-Saharan Africa firms: Aterido and HallwardDriemeier 2011; Latin American firms: Presbitero, Rabellotti, and Piras 2014). Unfortunately, our own data set on the Ethiopian manufacturing sector does not contain information on firms' ultimate decision makers to the extent that those are different from the owners. Rather, our data allow us to construct measures of female ownership based on the degree of control exercised by women in terms of both a firm's current capital shares and the composition of the corporate board. Importantly, Sekkat, Szafarz, and Tojerow (2015) demonstrate that developing country firms with women among their shareholders are more likely to have a female chief executive officer too. For African firms, it is found that the higher the female ownership share, the stronger its effect on the likelihood of having a female chief executive officer.

Our preferred measure of female ownership is based on a relatively restrictive definition, that is, whether women hold at least $50 \%$ of the current capital of firms. It is on the basis of such a definition that we present basic descriptive statistics and run our baseline regressions. Alternative definitions of female ownership will be used to check the robustness of our results further on in the paper.

Whereas the total number of firms increased substantially over the period considered (it more than doubled from 2003 to 2009), the share of femaleowned firms remained relatively stable at around $12 \%$ (cf. table A2). ${ }^{8}$

\footnotetext{
${ }^{7}$ For example, combining information from World Bank Enterprise Surveys with follow-up interviews of entrepreneurs in five African countries, Aterido and Hallward-Driemeier (2011) find no significant gender gaps in productivity when the standard female participation in ownership (based on capital shares) is used. However, when the actual primary decision maker is female, firms do exhibit significantly lower productivity.

${ }^{8}$ This share increases to $29 \%$ of the total sample if we consider a less restrictive definition (i.e., at least one woman among the owners) and reduces to $7.2 \%$ in case female ownership is defined as $100 \%$ of capital being held by women.
} 
Compared with their male-owned counterparts, female-owned firms are generally more concentrated both geographically (almost 60\% are located in the administrative region of Addis Ababa, which in turn accounts for about $49 \%$ of all firm-years in the sample) and especially at the sectoral level (more than $60 \%$ are found in the food processing and mineral products industries, dominated by bakeries and firms producing concrete, respectively; cf. tables A3, A4). In addition, and in correspondence with existing evidence from other developing countries, female-owned firms are smaller in size, less capital intensive, and less internationalized (i.e., engaged in exporting and/or importing) compared with male-owned firms. ${ }^{9}$ Moreover, on average, they employ larger shares of female workers overall and of skilled female workers in particular (cf. table 1).

Productivity estimates. The main indicator we use to measure the relative performance of male- and female-owned firms in this paper is productivity. We focus on TFP, an indicator widely employed in the literature on heterogeneous firms (Melitz 2003; Helpman, Melitz, and Yeaple 2004). The production function is assumed to take the form of a standard Cobb-Douglas specification:

$$
Y_{i t}=A_{i t} L_{i t}^{\beta_{l}} K_{i t}^{\beta_{k}} M_{i t}^{\beta_{m}}, \beta_{l}, \beta_{k}, \beta_{m}>0,
$$

where $Y_{i t}$ stands for the output of firm $i$ in year $t ; L_{i t}, K_{i t}$, and $M_{i t}$ are the inputs in the form of labor, capital, and intermediate inputs; $A_{i t}$ is the Hicks-neutral efficiency level, which represents the TFP of firms; and the $\beta$ s are factor shares. At the firm level, $A$ includes not easily measurable factors, such as $\mathrm{R} \& \mathrm{D}$ stocks, technology, quality, and marginal efficiency (Del Gatto, Di Liberto, and Petraglia 2011).

A transformation into logarithms allows us to introduce a linear estimation of the following production function (with small letters representing $\operatorname{logs})$ :

$$
y_{i t}=\beta_{0}+\beta_{l} l_{i t}+\beta_{k} k_{i t}+\beta_{m} m_{i t}+v_{i t}+\pi_{i t}
$$

where $\beta_{0}$ captures the mean efficiency across firms over time and the error term has two components: $v_{i t}$, which represents the level of productivity of the firm, and $\pi_{i t}$, the independently and identically distributed component

\footnotetext{
${ }^{9}$ Figure A1 plots the distributions of male- and female-owned firms' size, defined as the log of the number of employees. It shows the relative left shift of the female firm size distribution and the much fatter right tail of the male firm size distribution. The large majority of firms in our data set, both male and female owned, has between 10 (about 2.3 in log terms) and 150 (about 5 in logs) employees.
} 
TABLE 1

BASIC CHARACTERISTICS OF FIRMS BY OWNERSHIP

\begin{tabular}{lcc}
\hline Variable & Male Owned & Female Owned \\
\hline Number of employees & 86.116 & 35.679 \\
Sales (log) & 13.849 & 13.045 \\
Value added (log) & 13.776 & 12.958 \\
Fixed assets to number of employees (log) & 9.401 & 8.894 \\
Female/male workers (ratio) & .566 & .816 \\
Female/male skilled workers (ratio) & .545 & .824 \\
Exporter (dummy) & .0504 & .018 \\
Importer (dummy) & .676 & .595 \\
\hline
\end{tabular}

Source. Authors' elaborations on Central Statistical Agency manufacturing census data.

that is uncorrelated with input choices. ${ }^{10}$ The term $v_{i t}$ is the key variable to be computed after having estimated the production function and solved for $\omega_{i t}$ as the standard Solow residual:

$$
\hat{\omega}_{i t}=\hat{v}_{i t}+\hat{\beta}_{0}=y_{i t}-\hat{\beta}_{l} l_{i t}-\hat{\beta}_{k} k_{i t}-\hat{\beta}_{m} m_{i t} .
$$

Considering that $\hat{\omega}$ is observed by firms and influences their choice of inputs, making the error term correlated with the independent variables and rendering the coefficients of a standard ordinary least squares model biased, alternative methods to estimate TFP have been proposed in the literature, including fixed effects and system generalized method of moments estimators (for reviews, see Del Gatto, Di Liberto, and Petraglia 2011; Van Beveren 2012). More consistent approaches include those adopting semiparametric estimators using proxies to correct for unobservable productivity shocks and the potential simultaneity bias in the choice of input levels. In what follows, we focus on the approach proposed by Olley and Pakes (1996), which controls not only for the simultaneity bias but also for the potential selection bias resulting from the relationship between productivity shocks and the probability of firms exiting the market (which would bias the coefficient of capital downward if not properly accounted for). More specifically, the method of Olley and Pakes (1996) solves the simultaneity bias by using investment to proxy for unobserved time-varying productivity shocks, while the selection problems are addressed on the basis of survival probabilities.

\footnotetext{
${ }^{10}$ While both $v_{i t}$ and $\pi_{i t}$ are unobserved, the identification is grounded on the assumption that the former term is a state variable affecting the firm's decision-making process, while the latter, being either a measurement error or an unexpected shock to productivity, has no effect on the firm's decisions (Olley and Pakes 1996:1274).
} 
We estimate TFP separately for each industry, identified by its two-digit ISIC code. Output is measured by value added (calculated as total sales minus costs), labor is set equal to the total number of employees, capital is the book value of fixed assets, and intermediate inputs are proxied by the sum of all costs related to the materials used in the production process. Variables reported in monetary terms have been deflated using Ethiopia's gross domestic product deflator, obtained from the International Monetary Fund's World Economic Outlook database, with 2005 as the base year.

\section{Regression Results}

First, we are interested in evaluating whether the relative productivity gap of female-owned firms that has been found in most existing studies is also present in our census data on Ethiopian manufacturing firms. We estimate regressions of the following form:

$$
\hat{\omega}_{i t}=\gamma \text { Female }_{i t}+\eta^{\prime} X_{i t}+\delta_{j}+\theta_{r}+\lambda_{t}+\varepsilon_{i t},
$$

where $\omega_{i t}$ is $\log$ TFP; Female is our variable of interest, that is, a dummy identifying female ownership; $X_{i t}$ is a vector of control variables (see further); $\delta_{j}, \theta_{r}$, and $\lambda_{t}$ are industry $j$ dummies (based on the granular four-digit ISIC revision 3 classification), ${ }^{11}$ region $r$ dummies (based on first-order administrative unit classification), and year $t$ dummies, respectively; and $\varepsilon_{i t}$ is the error term. Standard errors are clustered at the firm level. Importantly, our identification strategy is based on within-industry variation in productivity according to the ownership of firms. Within-firm changes in ownership are relatively rare over the period considered and do not provide sufficient variation to properly interpret the effect of a switch from male to female ownership on productivity. ${ }^{12}$ Hence, our analysis will be mostly descriptive, documenting noteworthy correlations rather than presenting causal evidence.

\section{A. Unconditional Regression Estimates}

Table 2 summarizes the results of a first set of unconditional regressions linking female ownership to TFP.

The results are in line with extant evidence from other developing countries and show that, depending on the specification adopted, the productivity difference between female and male manufacturing firms in Ethiopia ranges

\footnotetext{
${ }^{11}$ In practice, at this level of detail, we observe 44 industry categories in our regression samples.

${ }^{12}$ Only about $4 \%$ of firms switched from male to female ownership over time, according to our preferred definition.
} 
TABLE 2

RESULTS OF UNCONDITIONAL ORDINARY LEAST SQUARES REGRESSIONS

\begin{tabular}{|c|c|c|c|c|c|}
\hline Variable & $\begin{array}{c}50 \% \text { Female } \\
\text { Ownership } \\
\text { of Capital } \\
\text { (1) }\end{array}$ & $\begin{array}{c}50 \% \text { Female } \\
\text { Ownership } \\
\text { of Capital } \\
\text { (2) }\end{array}$ & $\begin{array}{l}\text { Any Women } \\
\text { among } \\
\text { Owners } \\
\text { (3) }\end{array}$ & $\begin{array}{c}\text { 100\% Female } \\
\text { Ownership } \\
\text { of Capital } \\
\text { (4) }\end{array}$ & $\begin{array}{c}50 \% \text { Women } \\
\text { among } \\
\text { Owners } \\
\text { (5) }\end{array}$ \\
\hline Female & $\begin{array}{c}-.213^{\star \star} \\
(.104)\end{array}$ & $\begin{array}{c}-.292^{\star \star \star} \\
(.0676)\end{array}$ & $\begin{array}{c}-.140 \star \star \star \\
(.0464)\end{array}$ & $\begin{array}{c}-.513^{\star \star \star} \\
(.0926)\end{array}$ & $\begin{array}{c}-.280^{\star \star \star} \\
(.0681)\end{array}$ \\
\hline Constant & $\begin{array}{r}10.19 \star \star \star \\
(.0502)\end{array}$ & $\begin{array}{r}10.21^{\star \star \star} \\
(.0767)\end{array}$ & $\begin{array}{r}10.24^{\star \star \star} \\
(.0776)\end{array}$ & $\begin{array}{r}10.21^{\star \star \star} \\
(.0769)\end{array}$ & $\begin{array}{l}9.994^{\star \star \star *} \\
(.0801)\end{array}$ \\
\hline Observations & 7,727 & 7,726 & 7,726 & 7,726 & 6,811 \\
\hline$R^{2}$ & .001 & .655 & .654 & .657 & .632 \\
\hline Industry fixed effects & No & Yes & Yes & Yes & Yes \\
\hline Region fixed effects & No & Yes & Yes & Yes & Yes \\
\hline Year fixed effects & No & Yes & Yes & Yes & Yes \\
\hline
\end{tabular}

Note. Standard errors are clustered at the firm level. Dependent variable is log total factor productivity. Independent variable of interest is a dummy taking a value of 1 if female-owned capital is larger than $50 \%$ of the total in cols. 1 and 2; a dummy taking a value of 1 if there is at least one woman among the owners in col. 3; a dummy taking a value of 1 if female-owned capital is $100 \%$ in col. 4 ; and a dummy taking a value of 1 if there is a majority (50\%) of women among the owners of the firm in col. 5 .

** $p<.05$.

$\star * * p<.01$.

from $13 \%$ to $40 \%$ (calculated as $\mathrm{e}^{-0.140}-1$ and $\mathrm{e}^{-0.513}-1$ ), with a gap of $25 \%\left(e^{-0.292}-1\right)$ in a specification including a full set of industry, region, and year fixed effects.

The size of the productivity gap is sensitive to the exact definition of female ownership. In fact, the size of the estimated gap (of 25\%) using our preferred definition of female ownership based on a majority ( $50 \%$ or more) share of firm capital lies in between the gap for a broader definition based on the presence of at least one woman among the owners (col. 3; a gap of 13\%) and the gap for the most restrictive definition, that is, female ownership when all capital is held by women (col. 4; a gap of 40\%). ${ }^{13}$ This is consistent with the relatively wide range of estimates found by other studies, and it seems to confirm that what really matters to identify differences in firm performance is the extent of decision-making power rather than ownership per se (see also Aterido and Hallward-Driemeier 2011). While the distinction between ownership and decision-making is less meaningful for studies looking at microenterprises where the two concepts tend to overlap (de Mel, McKenzie, and Woodruff 2009; Bernhardt et al. 2017), it becomes more important when considering more structured firms like the ones we study here.

\footnotetext{
${ }^{13}$ Interestingly, using an alternative definition of female majority in ownership based on the number of owners results in an estimated coefficient that is very similar to the coefficient of our preferred (capital-based) female majority ownership measure (col. 5; corresponding to an estimated gap of 24\%).
} 


\section{B. Conditional Regression Estimates and Potential Mechanisms}

Having investigated the unconditional relation between female ownership and productivity, we now take the analysis further and try to improve our understanding of the origins of the observed gender productivity gap. First, we add a set of control variables likely to affect productivity levels that are typically used in heterogeneous firm models (Helpman, Melitz, and Yeaple 2004). These include firm size, defined as the log number of total employees (Employees); the age of the firm, that is, the log number of years since its first establishment (Age); capital intensity, measured as the log of the ratio of fixed assets to the number of employees (Capital Intensity); and two dummies controlling for the status of firms as Exporter and/or Importer. Second, we attempt a first exploration of the main mechanisms underlying the lower productivity of femaleowned firms by interacting our female ownership dummy with a range of firmand industry-specific factors.

The results of these additional regressions are reported in table 3. All standard controls behave as expected, in accordance with the provisions of heterogeneous firm models (Helpman, Melitz, and Yeaple 2004): older, larger, more capital-intensive and internationalized firms are marked by higher TFP. Most importantly, the existence of a gender-based productivity gap is again confirmed. As expected, the inclusion of firm-specific controls reduces the size of the gap, the estimated difference in productivity now being close to $12 \%$ $\left(e^{-0.125}-1\right)$, but its statistical significance remains high.

As demonstrated in figure 1, the size of our estimated productivity gap compares well with what is found in previous studies, especially with studies involving large-scale, formal firms in other sub-Saharan Africa countries.

In columns 2-7 of table 3, we explore some of the potential mechanisms at work by adding selected interaction terms. To ease interpretation, we have demeaned variables before interacting them with the female ownership dummy; the coefficient of the dummy can thus be read as the partial correlation between female ownership and $\log$ TFP when the interaction variable is evaluated at its average value.

Starting from column 2, where female ownership is interacted with capital intensity, we find that the observed gender gap in productivity increases with the use of capital. Whereas at the average value of $(\log )$ capital intensity, the estimated productivity disadvantage of female-owned firms is about $14 \%$, this rises to $24 \%$ when $(\log$ ) capital intensity is increased with one sample standard deviation. This is in line with existing studies demonstrating lower returns to capital for female-owned firms (although all these studies look at householdbased microenterprises; see, e.g., de Mel, McKenzie, and Woodruff 2008, 2009) and therefore a dimension that deserves more attention. Further results, 


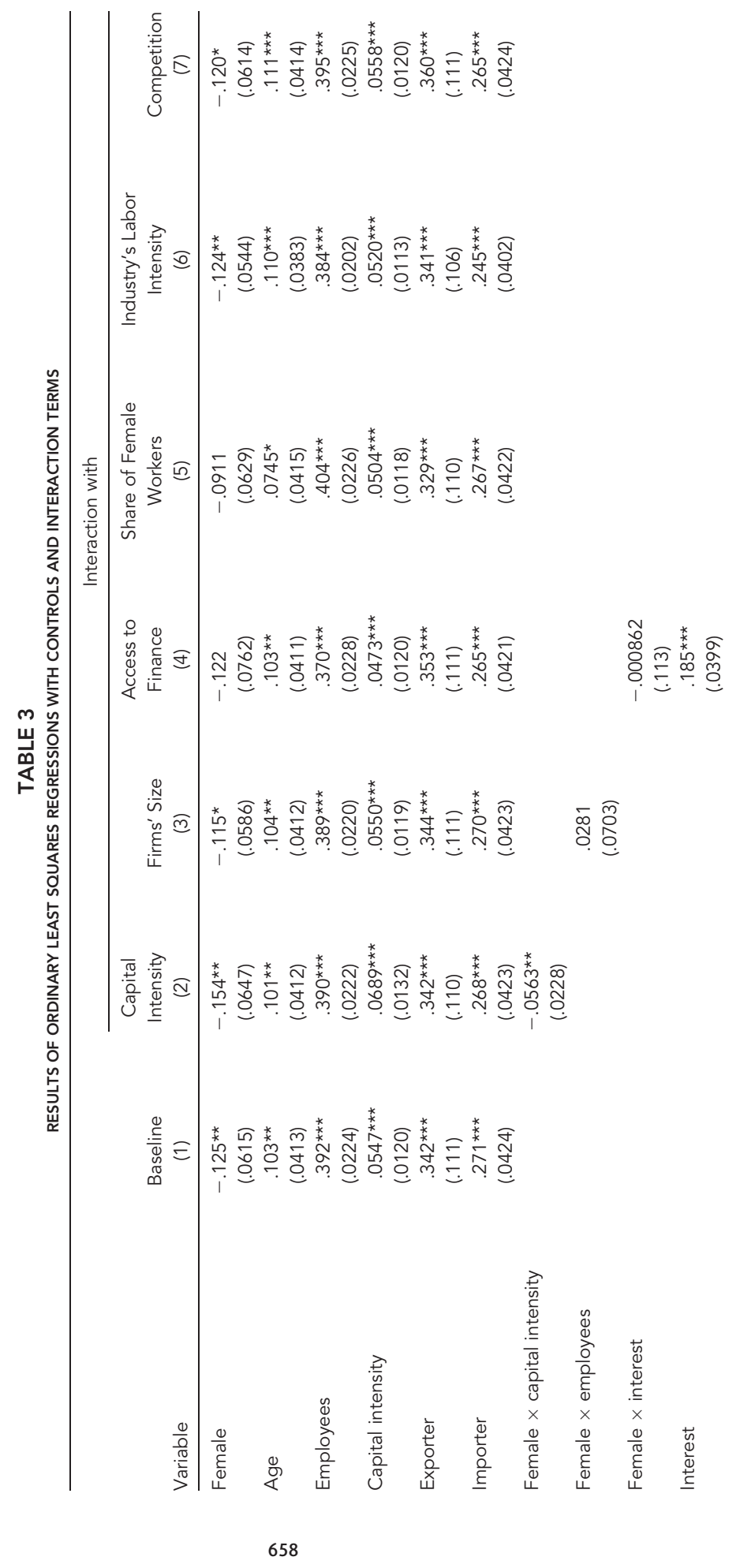




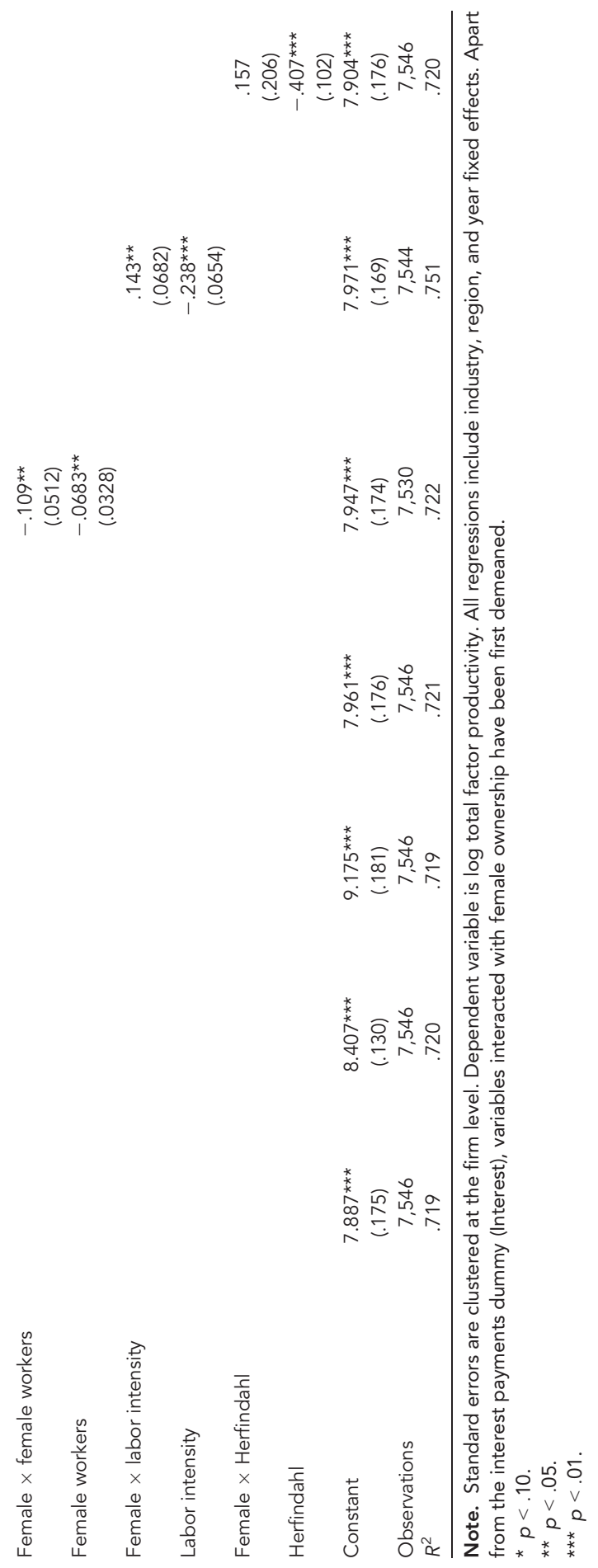




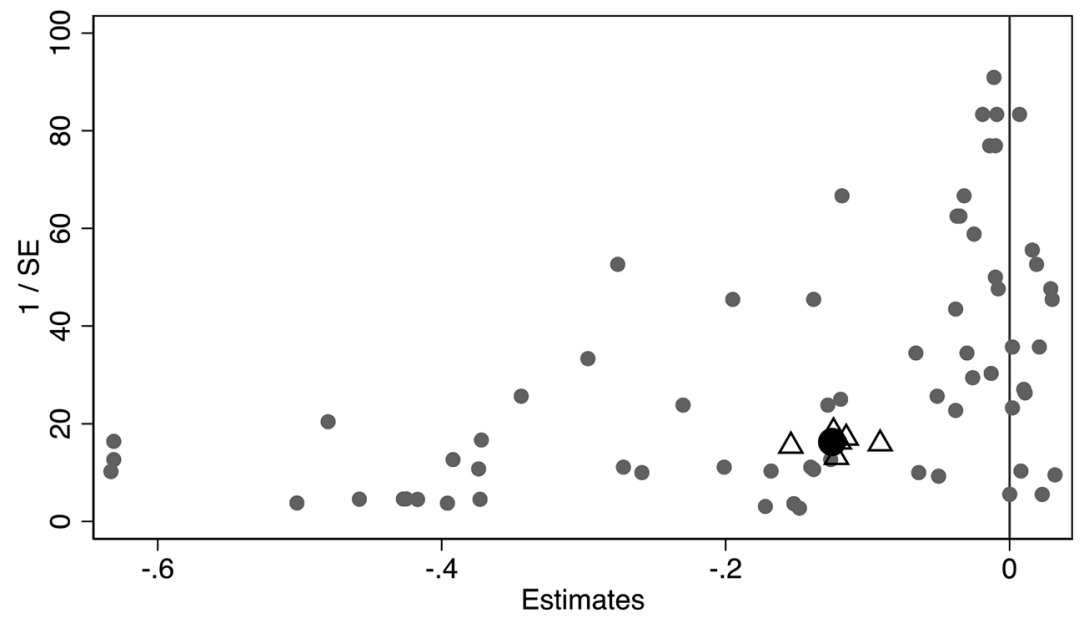

- Literature

This study (baseline, conditional reg. TABLE 3 Col. 1)

$\triangle$ This study (other estimates, conditional reg. TABLE 3)

Figure 1. Funnel plot of coefficient estimates and precision for this and relevant other studies. A funnel plot is commonly employed in the meta-analysis literature to see how estimates compare across studies (see, e.g., Egger et al. 1997). It serves as a visual aid to detect (publication) bias or systematic heterogeneity across different studies. Here the horizontal axis represents the coefficient of female ownership, capturing the estimated productivity gap between male- and female-owned firms. The vertical axis represents the inverse of the standard error of the corresponding coefficient, a measure of the precision of the estimate. The graph compares our baseline estimate of the female ownership coefficient from the conditional regression in column 1 of table 3 (and other table 3 estimates of the coefficient), with estimates in similar studies. The graph shows that most studies report negative coefficients, implying that female-owned firms are, on average, less productive than male-owned firms. The other studies included in this graph are Sabarwal and Terrell (2008), Rijkers et al. (2010), Aterido and Hallward-Driemeier (2011), Bardasi, Sabarwal, and Terrell (2011), and Jones (2012; cf. Sec. I).

reported in the remainder of this section and in Section IV.A on the decomposition analysis, confirm and help to better qualify this finding.

In columns 3 and 4, we do not find any evidence of mechanisms linking the productivity gap to either the size of the firm or to their access to finance. Our proxy for the latter is a dummy (Interest) taking a value of 1 if the firm reports positive values of interests paid (as in Shiferaw 2016, who uses the same census data). While we show that firms accessing finance tend to display higher productivity (of about $20 \%$ compared with firms that do not employ credit), the interaction term (col. 4) is not statistically significant. This implies that the use of credit neither amplifies nor attenuates productivity differences between male- and female-owned firms.

An important result is the one reported in column 5, where the role of female workers employed by the firm is considered (Female Workers; measures the ratio of female to male workers within each firm). The interaction term appears to indicate that the productivity gap can partly be attributed to those 
female-owned firms employing a large share of female workers, a factor that in itself is also found to be negatively correlated with productivity. According to the estimates, a female-owned firm with an average ratio of female to male workers (about 0.6 in the full sample) is characterized by a productivity gap of less than $9 \%$. If that ratio increases to 1 , the gap is almost $13 \%$. This result looks consistent with evidence reported by Hellerstein and Neumark (1999) on Israeli's manufacturing firms, but it is opposite to what Flabbi et al. (2016) find in a panel of Italian manufacturing firms. In their theoretical setting, Flabbi et al. (2016) claim that female executives are better at processing information on female workers, resulting in reduced discrimination (e.g., in wages) and, ultimately, improved firm performance (because of better matching of skilled female workers) when the share of female workers is higher. This does not seem to be the case in Ethiopia. Rather, our result likely derives from the clustering of female workers and owners in lower-productivity activities (Juhn, Ujhelyi, and Villegas-Sanchez 2014; Kucera and Tejani 2014).

In column 6, an industry-level measure of labor intensity (Labor Intensity; constructed from our census data by calculating each four-digit ISIC industry's share of total wages over capital) is interacted with female ownership. The positive coefficient of the interaction term is consistent with what we discussed above regarding firms' capital intensity (col. 2), as it shows that the productivity disadvantage of female-owned firms tends to be attenuated in more laborintensive industries.

A last finding from table 3 relates to the role of competition. When we add a variable measuring competition at the sectoral and regional level by means of an Herfindahl index (Herfindahl) for firms' sales, we do not see significantly different gender productivity gaps in more competitive markets (col. 7), unlike what is suggested by some studies reporting greater aversion of female owners toward competition and risk (Niederle and Vesterlund 2007). Since this is another dimension deserving more attention, we have run a set of additional (probit) regressions looking at gender-related differences in the probability of firm exit. The results, reported in table A5, show that the probability of exit of female-owned firms is not statistically different from that of their male counterparts, even after conditioning on observable firm characteristics and accounting for a possible bias due to the use of a representative surveyrather than the usual census-in 2005. Further analysis complementing these findings on firm survival is reported in Section IV.B.

Finally, results remain consistent if we employ different definitions of the dependent variable. When replacing TFP with labor or capital productivity, as we do in the estimates reported in table 4, we find that in both cases femaleowned firms exhibit a gap. Interestingly, and in line with the remainder of the 
TABLE 4

RESULTS OF ORDINARY LEAST SQUARES REGRESSIONS WITH ALTERNATIVE PRODUCTIVITY MEASURES

\begin{tabular}{lcc}
\hline & Labor Productivity & Capital Productivity \\
Variable & $(1)$ & $(2)$ \\
\hline Female & $-.0909^{\star}$ & $-.182^{\star \star}$ \\
Age & $(.0528)$ & $(.0740)$ \\
& $.208^{\star \star \star}$ & $.166^{\star \star \star}$ \\
Employees & $(.0416)$ & $(.0560)$ \\
& $.0636^{\star \star \star}$ & -.00465 \\
Capital intensity & $(.0204)$ & $(.0235)$ \\
& $.197^{\star \star \star}$ & $-.556^{\star \star \star}$ \\
Exporter & $(.0127)$ & $(.0277)$ \\
& .152 & .0282 \\
Importer & $(.0969)$ & $(.112)$ \\
& $.244^{\star \star *}$ & $.219 * \star \star$ \\
Constant & $(.0404)$ & $(.0581)$ \\
& $7.616^{\star \star \star}$ & $5.694^{\star \star \star}$ \\
Observations & $(.179)$ & $(.322)$ \\
$R^{2}$ & 7,725 & 7,700 \\
\hline
\end{tabular}

Note. Standard errors are clustered at the firm level. Dependent variable is the log of labor productivity (ratio of sales to employment) in col. 1 and the log of capital productivity (ratio of sales to capital) in col. 2. All regressions include industry, region, and year fixed effects.

$\star p<.10$.

$\star \star *<<.05$.

$\star \star \star ~ p<.01$

paper, we find a larger average gap in terms of capital productivity (almost 17\% compared with an average labor productivity gap of less than 9\%).

\section{Results on Firm Productivity Distributions}

In this section, we move beyond average gender gaps in firm productivity and analyze differences between the respective productivity distributions of maleand female-owned firms in our Ethiopian census data. We first apply the quantile decomposition approach developed by Firpo, Fortin, and Lemieux (2007) to distinguish between composition and structural effects in explaining gender productivity gaps at different points of the overall distribution. Next, we employ the methodology developed by Combes et al. (2012) to conduct a formal comparison of the shift, dilation, and truncation of productivity distributions between female- and male-owned firms. The two approaches complement each other. Whereas the Combes et al. (2012) approach adds structure to our analysis by testing for very specific and intuitive distributional differences between female- and male-owned firms' productivity, it may be less informative about potential channels driving such differences. The latter are more explicitly captured by the Firpo, Fortin, and Lemieux (2007) approach, which compares the 
two distributions on the basis of differences in observable and nonobservable factors.

\section{A. Decomposition Analysis}

The decomposition method developed by Firpo, Fortin, and Lemieux (2007) allows us to look at the productivity gap between male- and female-owned firms at different points in the productivity distribution and to identify how much of the gap can be explained by differences in observable characteristics or, alternatively, by differences in returns to those characteristics. Using their terminology, the former is labeled the "composition effect" and the latter the "structural effect."

More specifically, this methodology generalizes the standard Oaxaca-Blinder decomposition to different quantiles of the distribution, following a three-step procedure. ${ }^{14}$ First, the productivity $(\log$ TFP) distribution of male-owned firms is reweighted so that the just-mentioned composition effect is controlled for. If we label this reweighted distribution as $\Omega_{c}$ and use $\Omega_{m}$ and $\Omega_{f}$ to indicate the original male and female distributions, this implies that the productivity gap between male- and female-owned firms - for example, at the mediancan be written as

$$
\Delta_{0.5}=\left[\Omega_{m}(0.5)-\Omega_{c}(0.5)\right]-\left[\Omega_{c}(0.5)-\Omega_{f}(0.5)\right],
$$

where the first term represents the composition effect and the second term the structural effect, evaluated at the median. In a next step, recentered influence functions (RIFs) are computed for each quantile of the three distributions $\Omega_{m}$, $\Omega_{f}$, and $\Omega_{c}$. As the name suggests, an RIF of a distributional statistic, such as a quantile, represents the influence that an individual observation has on that distributional statistic and is constructed in such a way that its mean corresponds to the statistic of interest. More formally, in the case of quantiles, we have

$$
\operatorname{RIF}\left(\Omega ; Q_{\tau}\right)=Q_{\tau}+\frac{\tau-I\left\{\omega \leq Q_{\tau}\right\}}{f_{\Omega}\left(Q_{\tau}\right)},
$$

where $I$ is an indicator function, $f_{\Omega}$ is the marginal density of $\Omega$, and $Q_{\tau}$ is the population $\tau$ th quantile of the unconditional distribution $\Omega$. Then, RIF quantile regression models are fitted on the basis of a specification similar to equation (4) and also using ordinary least squares but where the dependent variable is replaced by the corresponding RIF for the quantile of interest. Finally, in the third and last step, the gender-based firm productivity gap at each quantile is decomposed in a standard Oaxaca-Blinder fashion. For the median, we obtain

\footnotetext{
${ }^{14}$ Our presentation of the methodology follows that of Nix, Gamberoni, and Heath (2016).
} 


$$
\begin{aligned}
\hat{q}_{0.5}\left(\Omega_{m}\right)-\hat{q}_{0.5}\left(\Omega_{f}\right)= & \underbrace{\sum_{j} E\left[X_{j, m}\right]\left(\hat{\eta}_{j, m}-\hat{\eta}_{j, c}\right)}_{\hat{\Delta}_{s}=\text { structural effect }}+R_{0.5}^{S} \\
& +\underbrace{\sum_{j} E\left[X_{j, m}\right] \hat{\eta}_{j, c}-\sum_{j} E\left[X_{j, f}\right] \hat{\eta}_{j, f}}_{\hat{\Delta}_{c}=\text { composition effect }}+R_{0.5}^{C},
\end{aligned}
$$

where $X$ and $\eta$ represent the covariate vector and vector of coefficients as in equation (4) and the $R^{\prime}$ s are approximation errors due to the structural and composition effects (as the RIF regressions involve first-order approximations).

A more detailed and technical description of the methodology can be found in Firpo, Fortin, and Lemieux (2007, 2009), whereas Nix, Gamberoni, and Heath (2016) provide an application of the methodology to a research question similar to ours. This latter study shows that a significant part of the performance gap of female-owned microenterprises in four sub-Saharan Africa countries can be explained by structural effects.

The main results of applying the decomposition analysis to our data are summarized in figure 2. Figure 2 shows differences in firm productivity across gender and decomposes them into composition and structural effects at each decile of the productivity distribution. It demonstrates that differences in productivity increase when moving toward the upper tails of the distribution (where

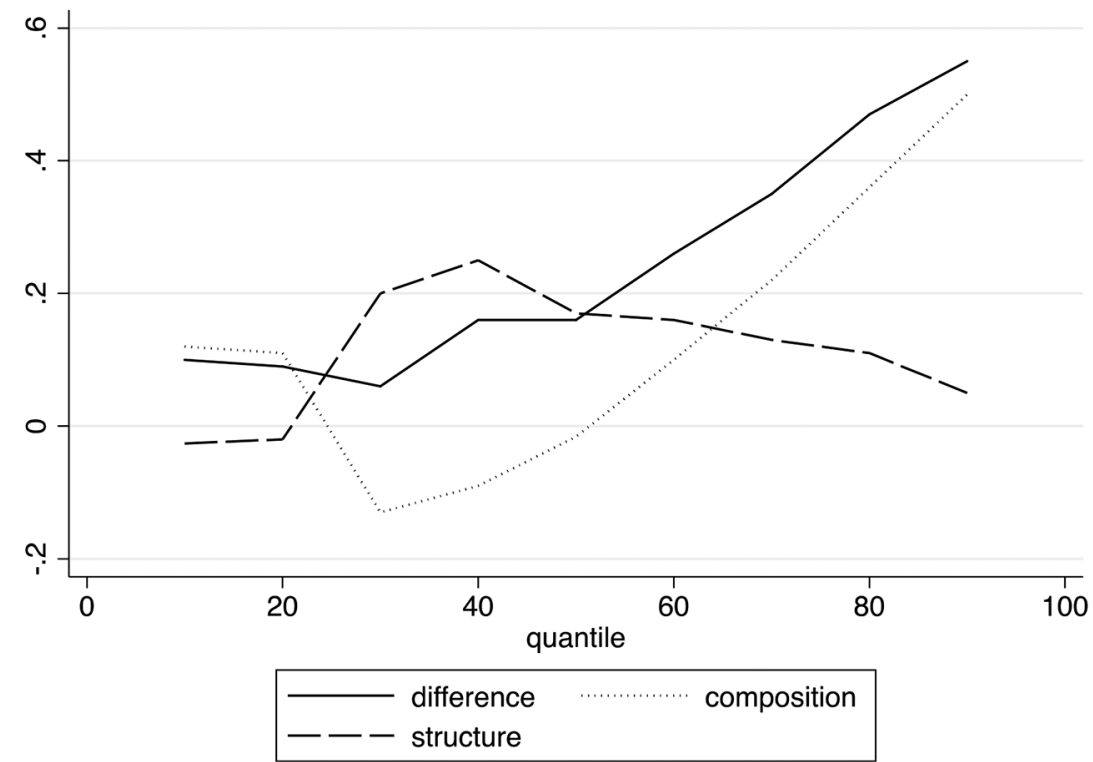

Figure 2. Results of decomposition analysis. This graph shows male-female differences in firm productivity (log total factor productivity) at each decile of the productivity distribution and their decomposition into (observed) composition and (unobserved) structural effects according to the approach of Firpo, Fortin, and Lemieux $(2007,2009)$. 
female-owned firms are less represented) and that in the tails composition effects have the highest explanatory power. Conversely, structural effects are largely responsible for the productivity differences observed in the central part of the distribution, that is, from the third to sixth decile. No clear differences among the two types of effects are observed in the bottom deciles.

The Firpo, Fortin, and Lemieux (2007) approach also makes it possible to disentangle the contribution of the individual variables (see table A6). Importantly, over the central quantiles of the distribution, the role of capital appears to be crucial. Returns to capital account for most of the unobserved part of the productivity differences; often it is the only significant component of the structural effect. However, observable characteristics related to the size, capital intensity, and internationalization of firms are the main factors accounting for the larger male-female productivity differences linked to the composition effect that we observe when moving toward the upper tails of the distribution.

\section{B. Differences in Productivity Distributions}

Combes et al. (2012) study the positive correlation between city size and firm productivity and present a quantile-based approach to discriminate empirically between two common explanations, that is, firm selection and agglomeration economies. Supported by a theoretical model incorporating both firm entry/ exit and between-firm interactions, they show that stronger firm selection in larger cities should result in a left truncation of the productivity distribution of firms active there, whereas stronger agglomeration effects should lead to a right-shifted and-if more productive firms are also better able to exploit such agglomeration economies-more dilated productivity distribution. Since making proper inference about relative shift, dilation, and truncation by eyeballing the differences in shape of two distributions can be difficult, Combes et al. (2012) translate their theoretical framework into a quantile-based estimator that allows them to formally identify and test shift, dilation, and truncation parameters. ${ }^{15}$ It is this estimator that we transplant to our specific context. As pointed out by Kondo (2017), the Combes et al. (2012) quantile approach can be applied more generally outside the fields of urban economics and economic geography to compare any two (productivity) distributions. ${ }^{16}$

\footnotetext{
${ }^{15}$ In general terms, the estimation approach minimizes the errors in matching the quantiles of the two distributions concerned and relies on a two-step-iterated numerical optimization (with iterations over the truncation parameter and over combinations of the shift and dilation parameters). For more technical details, see Combes et al. (2012) and Kondo (2017).

${ }^{16}$ That notwithstanding, most papers employing the Combes et al. (2012) methodology stay close to the original setup of comparing firm productivity between larger and smaller cities (see, e.g., Kondo 2016). We are not aware of other studies using it to compare firm productivity along gender dimensions.
} 
The main value added of the Combes et al. (2012) approach over the traditional regression results we presented in Section III is that it provides additional insights beyond the average productivity gap of female-owned firms based on very specific distributional parameters. For example, are productivity gaps systematically observed over the whole distribution, and/or are they reinforced by differences between the top-performing female- and male-owned firms? And to what extent are productivity gaps also explained by gender differences in the relative heterogeneity of firms? Unlike the decomposition methodology of Firpo, Fortin, and Lemieux (2007), which considers the influence of covariates at different quantiles of the distribution, the Combes et al. (2012) methodology summarizes the differences in productivity distributions of male- and female-owned firms in three intuitive transformation parameters (shift, dilation, and truncation), thus providing a complementary perspective.

To better understand the gist of Combes et al.'s (2012) approach, let us consider two cumulative distributions, $F_{f}$ for female-owned firms and $F_{m}$ for maleowned firms, with some common underlying distribution $F$. Further assume that $F_{f}\left(F_{m}\right)$ can be obtained by shifting $F$ rightward by a constant $A_{f}\left(A_{m}\right)$, dilating $F$ by a factor $D_{f}\left(D_{m}\right)$, and left-truncating a share $S_{f}\left(S_{m}\right) \in[0,1[$ of $F$; or mathematically,

$$
\begin{aligned}
& F_{f}(\omega)=\max \left\{0, \frac{F\left[\left(\omega-A_{f}\right) / D_{f}\right]-S_{f}}{1-S_{f}}\right\}, \\
& F_{m}(\omega)=\max \left\{0, \frac{F\left[\left(\omega-A_{m}\right) / D_{m}\right]-S_{m}}{1-S_{m}}\right\},
\end{aligned}
$$

where $\omega$ again stands for productivity or, more specifically, $\log$ TFP. Moreover, if we define $D \equiv D_{f} / D_{m}, A \equiv A_{f}-D A_{m}$, and $S \equiv\left(S_{f}-S_{m}\right) /\left(1-S_{m}\right)$, then it is relatively straightforward to show that the following relationship between $F_{f}$ and $F_{m}$ holds: $:^{17}$

$$
\begin{aligned}
& F_{f}(\omega)=\max \left\{0, \frac{F_{m}[(\omega-A) / D]-S}{1-S}\right\} \text { if } S_{f}>S_{m}, \\
& F_{m}(\omega)=\max \left\{0, \frac{F_{f}(D \omega+A)-[-S /(1-S)]}{1-[-S /(1-S)]}\right\} \text { if } S_{f}<S_{m} .
\end{aligned}
$$

This relation indicates that one distribution (e.g., $F_{f}$ ) can be obtained as a transformation of the other (e.g., $F_{m}$ ) without having to specify the common underlying distribution $F$. Combes et al. (2012) translate the above expressions in

\footnotetext{
${ }^{17}$ The simple proof of this relation can be found in app. C of Combes et al. (2012:2589-90).
} 
quantile functions that can be estimated to derive parameters $A, D$, and $S$, that is, the relative shift, relative dilation, and relative left truncation, respectively, that need to be applied to $F_{m}$ to approximate $F_{f}$.

Given our previous regression results on the average productivity gap, we expect the TFP distribution of female-owned firms to be left shifted relative to the male distribution $(A<0)$. Besides such a general productivity disadvantage, we may also expect relatively stronger homogeneity in productivity among female firms because of their concentration in lower-productivity industries, smaller scale, and lower capital intensity. Ceteris paribus, this should be reflected in a less dilated TFP distribution for female- than for male-owned firms $(D<1)$. Finally, we do not have very strong priors on the relative truncation parameter, especially since we do not find significant gender differences in firm exit (cf. table A5).

Table 5 presents the parameters for relative shift $(A)$, dilation $(D)$, and truncation $(S)$ for the female- versus male-owned firm productivity distributions, estimated using Combes et al.'s (2012) quantile approach. ${ }^{18}$ Productivity is here defined as the average log TFP for each firm over the available (maximum 7) years of data. The reported standard errors are obtained using 500 bootstrap replications, and significance is based on two-sided $z$-tests of the respective null hypotheses that $A=0, D=1$, and $S=0 .{ }^{19}$

As can be seen in the first row of table 5, when we consider our full sample of female- and male-owned firms, we find a negative value for $A$ of about -0.140 , which is also highly significant. This means that to move from the male to the female average TFP distribution, one needs to shift the former distribution

${ }^{18}$ As in Combes et al. (2012), we trim the extreme (bottom/top 1\%) values of firm-level TFP (separately for female- and male-owned firms) to obtain more reliable and unbiased estimates of the parameters $A, D$, and $S$.

${ }^{19}$ To produce these results, we have used the estquant command in Stata developed by Kondo (2017). As a robustness check, we have also performed the same analysis using the original SAS code of Combes et al. (2012). Both codes yield nearly identical point estimates for $A, D$, and $S$. However, the latter requires much longer computational time for larger numbers of bootstrap iterations. To deal with the small subsample of female firms (about 250), bootstrap sampling is stratified on the gender of ownership, and bootstrap samples where less than $50 \%$ of the original female firms are represented are discarded. This ensures that our bootstrap samples include a sufficient number of unique female firms. Further stratification of bootstrap sampling on sectors or regions is employed in view of large sectoral/regional heterogeneity in productivity. See table 5 for details. As in Combes et al. (2012), we also report in table 5 a measure of explanatory power, which is calculated as

$$
R^{2}=1-\frac{M(\hat{A}, \hat{D}, \hat{S})}{M(0,1,0)}
$$

where $M$ is the criteria function minimized by Combes et al.'s (2012) estimator. In other words, this pseudo $R^{2}$ indicates how much of the mean squared quantile difference between female and male firm productivity distributions is explained by the three parameters. 
TABLE 5

RESULTS OF COMPARISON OF PRODUCTIVITY DISTRIBUTIONS

\begin{tabular}{|c|c|c|c|c|c|c|}
\hline Category/Sector & $\begin{array}{l}\text { Shift } \\
(A) \\
(1)\end{array}$ & $\begin{array}{l}\text { Dilation } \\
\text { (D) } \\
\text { (2) }\end{array}$ & $\begin{array}{l}\text { Truncation } \\
\text { (S) } \\
\text { (3) }\end{array}$ & $\begin{array}{l}R^{2} \\
(4)\end{array}$ & $\begin{array}{l}\text { Observations } \\
\text { (5) }\end{array}$ & $\begin{array}{c}\text { Female-Owned } \\
\text { Firms (\%) } \\
\text { (6) }\end{array}$ \\
\hline $\begin{array}{l}\text { 1. Female owned vs. male } \\
\text { owned, full sample }\end{array}$ & $\begin{array}{c}-.140 \star \star \star \\
(.0089)\end{array}$ & $\begin{array}{l}.855^{\star \star \star} \\
(.0037)\end{array}$ & $\begin{array}{l}-.0115^{\star \star \star} \\
(.0012)\end{array}$ & .867 & 2,465 & 10.14 \\
\hline $\begin{array}{l}\text { 2. Female owned vs. male } \\
\text { owned, Addis Ababa only }\end{array}$ & $\begin{array}{c}-.306 \star \star \star \\
(.0126)\end{array}$ & $\begin{array}{l}.872^{\star \star \star} \\
(.0049)\end{array}$ & $\begin{array}{l}.00213 \\
(.0012)\end{array}$ & .902 & 998 & 13.63 \\
\hline $\begin{array}{l}\text { 3. Female owned vs. male } \\
\text { owned, food and beverages } \\
\text { sector only (ISIC 15) }\end{array}$ & $\begin{array}{c}-1.232^{\star \star \star} \\
\quad(.1525)\end{array}$ & $\begin{array}{l}.973 \\
(.0676)\end{array}$ & $\begin{array}{l}.00425 \\
(.0886)\end{array}$ & .990 & 561 & 16.22 \\
\hline $\begin{array}{l}\text { 4. Female owned vs. male } \\
\text { owned, mineral products } \\
\text { sector only (ISIC 26) }\end{array}$ & $\begin{array}{l}-.105^{\star \star \star} \\
(.0165)\end{array}$ & $\begin{array}{l}.857^{\star \star \star} \\
(.0207)\end{array}$ & $\begin{array}{r}-.0174^{\star} \\
(.0083)\end{array}$ & .500 & 682 & 13.64 \\
\hline $\begin{array}{l}\text { 5. Female owned vs. male owned, } \\
\text { full sample (residual distribu- } \\
\text { tion, controlling for sectors) }\end{array}$ & $\begin{array}{c}-.386 * \star \star \\
(.0152)\end{array}$ & $\begin{array}{l}1.098^{\star \star \star} \\
(.0205)\end{array}$ & $\begin{array}{l}.00442 \\
(.0039)\end{array}$ & .894 & 2,465 & 10.14 \\
\hline $\begin{array}{l}\text { 6. Female owned vs. male owned, } \\
\text { full sample (residual distribu- } \\
\text { tion controlling for sectors, } \\
\text { number of employees, and } \\
\text { capital intensity) }\end{array}$ & $\begin{array}{c}-.226 * \star \star \\
(.0065)\end{array}$ & $\begin{array}{l}1.102^{\star \star \star} \\
(.0043)\end{array}$ & $\begin{array}{l}-.00345^{\star \star \star} \\
(.0010)\end{array}$ & .949 & 2,446 & 10.14 \\
\hline
\end{tabular}

Note. Results are based on the quantile approach developed by Combes et al. (2012) and use average log total factor productivity as the productivity measure. Bootstrapped standard errors (using 500 replications) are in parentheses. Bootstrap sampling is stratified on gender of ownership and on either sector (lines 1 and 2) or region (lines 3-6) and uses only samples where at least $50 \%$ of the original female-owned firms are represented. ISIC = International Standard Industrial Classification.

${ }^{*} p<.10$.

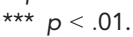

leftward (cf. fig. 3), which, on its own (without considering dilation and truncation), implies a decrease in mean productivity of just over $13 \%\left(\mathrm{e}^{-0.140}-1\right)$. Moreover, in the full sample, $D<1$, meaning that the female firms' TFP distribution is less dilated than the male distribution. This is a relevant property, since it reflects the relative homogeneity of female-owned firms, which appear to be less likely to succeed in achieving high productivity than male firms. Finally, we also find evidence of some (statistically significant but economically small) truncation differences in the full sample. More specifically, we uncover an $S<0$, suggesting that overall, female firms are somewhat more likely to stay in the market even at lower productivity levels compared with male firms. While it is not possible to identify the exact underlying mechanisms with the data at hand, one possible interpretation could be a relatively more cautious approach to business by female owners (Niederle and Vesterlund 2007). Another 


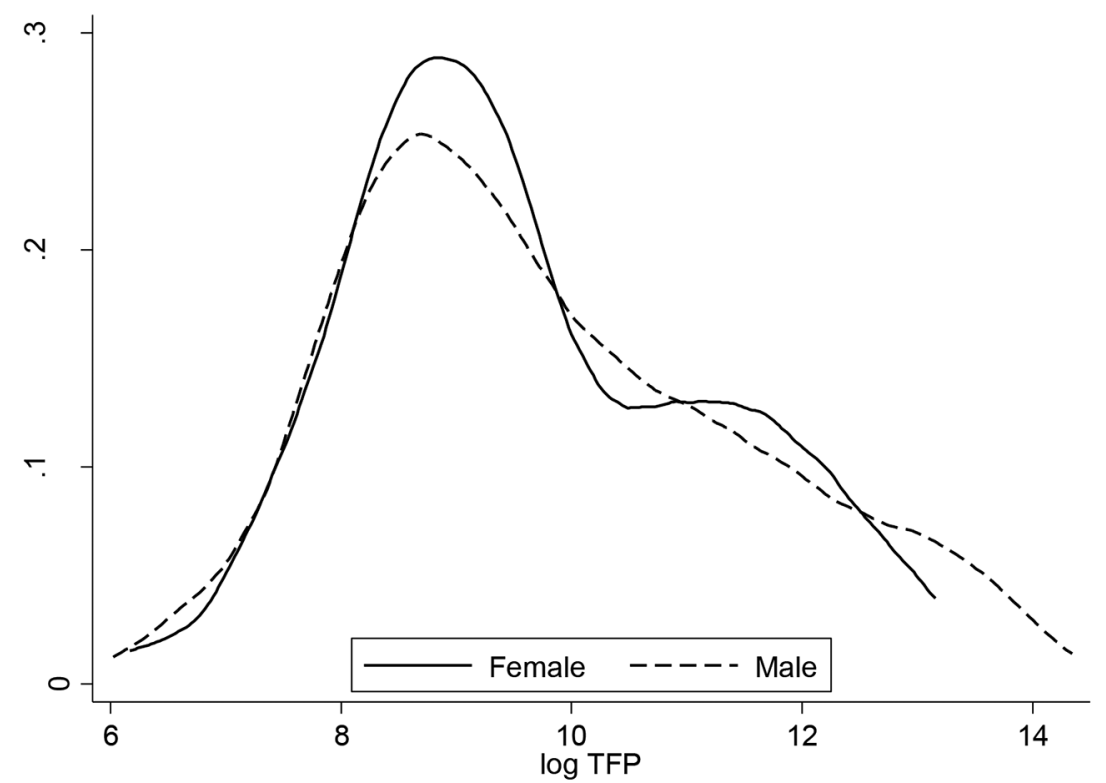

Figure 3. Female- versus male-owned firm productivity distributions, full sample. Densities of log total factor productivity (TFP) distributions are estimated using an Epanechnikov kernel function and a bandwidth that minimizes the mean integrated squared error under Gaussian assumptions. Top and bottom 1\% of log TFP distributions are trimmed (separately for male and female distributions).

interpretation is that the high gender discrimination in the Ethiopian labor market perhaps provides an extra incentive for women to keep running their own businesses, even when they are comparatively unproductive.

Overall, these results very well complement and further qualify those of the decomposition analysis, especially for what concerns the tails of the distribution. In table A7, we report some descriptive statistics on the firms populating the top and bottom $10 \%$ of the overall productivity distribution, differentiating by gender of the owners. Male- and female-owned firms at the bottom of the productivity distribution look relatively similar as far as main endowments are concerned. This is consistent with the moderate compositional effects at the first decile we observe in figure 2. Two notable exceptions are that femaleowned firms employ many more female workers and that they are operating at a lower scale of activity. At the top 10\% of the distribution, on the contrary, marked gender differences are observed in almost all observable firm characteristics, including number of employees, capital endowments, and internationalization status, again consistent with the findings of the decomposition analysis (cf. fig. 2). The few female-owned firms that do make it to the top $10 \%$ of most productive firms do so in spite of large differences in the observables. The very small number of such outstanding female-owned firms likely explains part of 
the lower distribution dilation (relative to male-owned firms) that we have documented using the Combes et al. (2012) approach.

Further results based on differences in productivity distributions. The second row of table 5 shows our estimates for the three transformation parameters of the TFP distributions when considering only firms based in the neighborhood of the capital, Addis Ababa (cf. fig. A2). Our choice to look into Addis Ababa separately is motivated by the very strong presence of manufacturing firms in the Addis region (about half of our sample) and by the literature emphasizing the specific productivity advantages of being located in larger agglomerations (e.g., Combes et al. 2012; Kondo 2016), including in sub-Saharan Africa (Sanfilippo and Seric 2016). ${ }^{20}$ The relative left shift in the female productivity distribution is economically more significant in Addis Ababa than in the full sample (implying a 26\% lower TFP at the mean), and also the lower dilation is again clear. However, the truncation parameter is no longer statistically significant. We thus conclude that there are no strong survival differences between Addis Ababa-based female- and male-owned firms.

In rows 3 and 4 of table 5, we list our results for the TFP distributions of firms operating within the food processing and mineral products industries, respectively (cf. figs. A3, A4). These are two manufacturing industries in which female owned-firms are relatively well represented, even if female-owned firms in no way dominate these industries (see col. 6 of table 5; table A4). ${ }^{21}$ As in the full sample, we again observe, in both sectors, relative left shifts and lower dilation for the female versus male firm productivity distributions. Yet there is considerable heterogeneity, as the shift is particularly strong for the laborintensive food processing industry, while dilation (and, to a lesser extent, truncation) is most evident in the mineral products sector. The finding that maleowned firms on average outperform female-owned firms also within these two sectors (especially so in food processing) could have various reasons. It may be

\footnotetext{
${ }^{20}$ For the specific case of Ethiopia, Rijkers, Söderbom, and Loening (2010) carry out a rural-urban comparison of manufacturing firms and find that the benefits associated with agglomeration are concavely related to city sizes. They argue that firms in remote rural areas are much less productive than firms located elsewhere, but they fail to uncover big productivity differences between rural towns and major urban areas. However, Siba et al. (2012) study the effect of firm clustering on output prices and productivity in Ethiopia and find a positive and statistically significant relationship between the density of firms that produce a given product and productivity.

${ }^{21}$ Despite the overrepresentation of female-owned firms in these sectors, there are also many maleowned firms found there not only as a share of all male-owned firms (cf. table A4) but also in absolute terms (with still many more male-owned than female-owned firms operating in these sectors, in fact). In other words, even if female business owners are heavily concentrated in these sectors (representing more than $60 \%$ of all female-owned firms), food processing and mineral product production are not dominated by female-owned firms.
} 
due to, for instance, an engagement in different, more profitable or capitalintensive subsector activities. In the food processing industry, female-owned business are almost exclusively bakeries, whereas male-owned firms are also flour and edible oil manufacturers. Within mineral products, female firms produce mostly concrete, while male firms produce mostly concrete and other nonmetallic products.

Finally, we perform two additional exercises on the full sample: we regress log TFP on either (1) four-digit ISIC industry dummies or (2) industry dummies, firm size (log number of employees), and capital intensity and then apply the Combes et al. (2012) approach to the regression residuals. The results are shown in rows 5 and 6 of table 5 (cf. also figs. A5, A6). We again find a significant relative left shift of the female firms' productivity distribution, moreover one that is economically larger than in the unconditional full-sample estimates of row 1 . The earlier truncation differences disappear. And, interestingly, once sectoral composition is controlled for, the productivity distribution of female firms is actually slightly more dilated than that of their male counterparts (i.e., $D>1$ ). This seems to suggest that the relative homogeneity (smaller dispersion) in female firms' productivity overall relates to their concentration in certain lowerproductivity sectors.

\section{Concluding Remarks}

In this paper, we have investigated whether and how productivity differs between female- and male-owned firms in Ethiopia. Using census data on manufacturing firms over the 2003-9 period, we provide robust evidence of a productivity disadvantage for female-owned firms, which can be plausibly linked to factors such as their size, endowments (of capital in particular), differences in returns to those endowments (again, primarily returns to capital), and specialization/sorting into less productive subsectors.

Our findings underline the importance of moving beyond standard analysis based on the average productivity gap. The various methodologies we apply demonstrate how there might be different gaps, diverse mechanisms leading to them, and hence different explanations for their existence. For instance, on the basis of formal comparisons of productivity distributions, we show that one important mechanism underlying the gender-based firm productivity gap is a higher homogeneity in terms of productivity coupled with the relative lack of highly productive female-owned firms.

One issue that also emerges from our distributional analyses is that, whereas many of the gaps recorded at the upper tail of the productivity distribution seem to be linked to observed firm-level characteristics, such as firm size and capital intensity, nonnegligible productivity differences found in the more central part 
of the distribution tend to derive from other factors (in particular, returns to capital) that are more difficult to capture with our data. Further research, including more in-depth, qualitative work, is therefore needed to get a fuller understanding of the key factors explaining the performance gaps of female-owned firms in Ethiopia.

Still, we believe our findings so far provide valuable policy lessons for a country like Ethiopia, currently embarked on a process of structural transformation, in which productivity growth in the manufacturing sector will be crucial. The literature on resource misallocation shows that persistent productivity gaps across manufacturing firms result in lower aggregate productivity (Hsieh and Klenow 2009), suggesting that there are gains to be made from shutting down unproductive firms and reallocating their resources to other more productive firms. In our context, bluntly applying such logic of improving allocative efficiency would imply leaving many female-owned firms behind. However, the promotion of an active role for women as decision makers and owners of economic resources, including through the encouragement of female-owned firms, seems an important goal in itself and a key ingredient of any inclusive, broad-based process of structural transformation. Supporting female-owned firms while limiting the cost of allocative inefficiencies requires a deeper understanding of the extent, nature, and origins of their productivity gaps vis-à-vis male-owned firms. This is indeed what this paper attempts to contribute to. Above all, our paper demonstrates that in Ethiopia, heterogeneous forces are at work behind the average male-female firm productivity gap. Arguably, closing productivity gaps that relate to the limited use of capital or smaller firm size will require different kinds of interventions than addressing gaps that result from lower returns to capital or yet another source, such as the concentration in particular subsectors. It also makes a difference whether one targets a muchconstrained female-owned firm at the lower end of the productivity distribution or, alternatively, a moderately productive firm that misses some key inputs to really stand out. We hope future research will shed further light on the various mechanisms this paper has briefly documented in order to inform the design of appropriate policy packages. 


\section{Appendix}

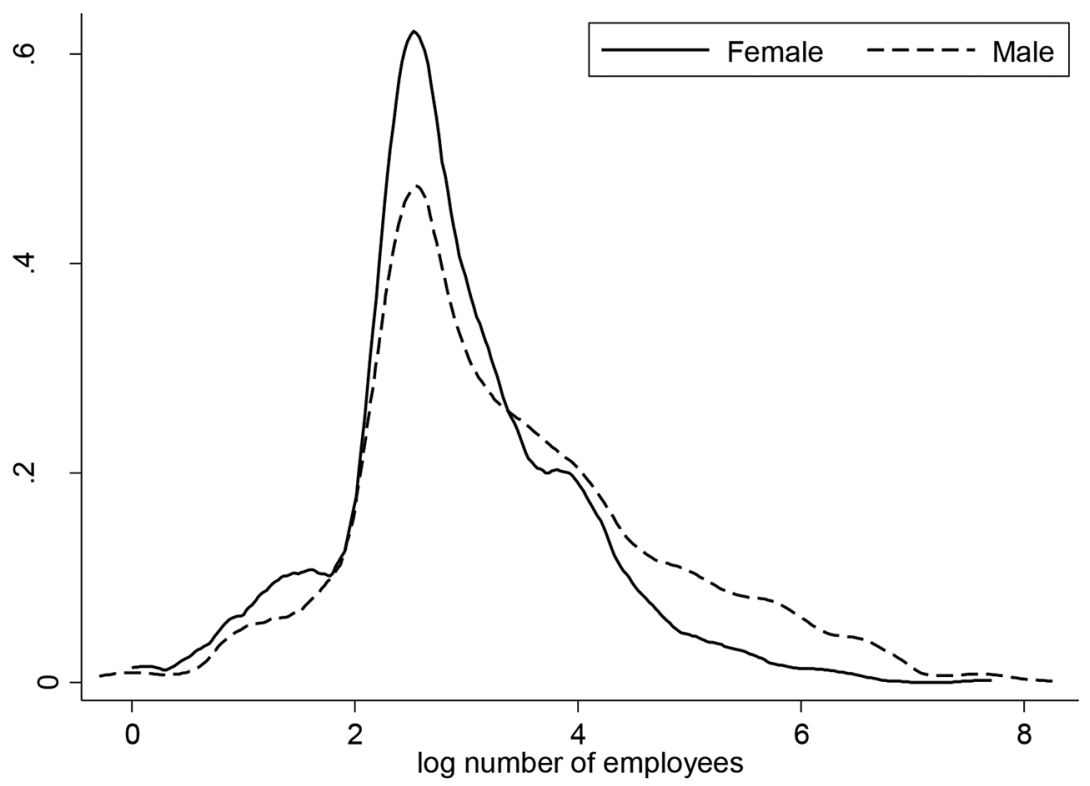

Figure A1. Female- versus male-owned firm size distributions. Densities of log number of employee distributions are estimated using an Epanechnikov kernel function and a bandwidth that minimizes the mean integrated squared error under Gaussian assumptions.

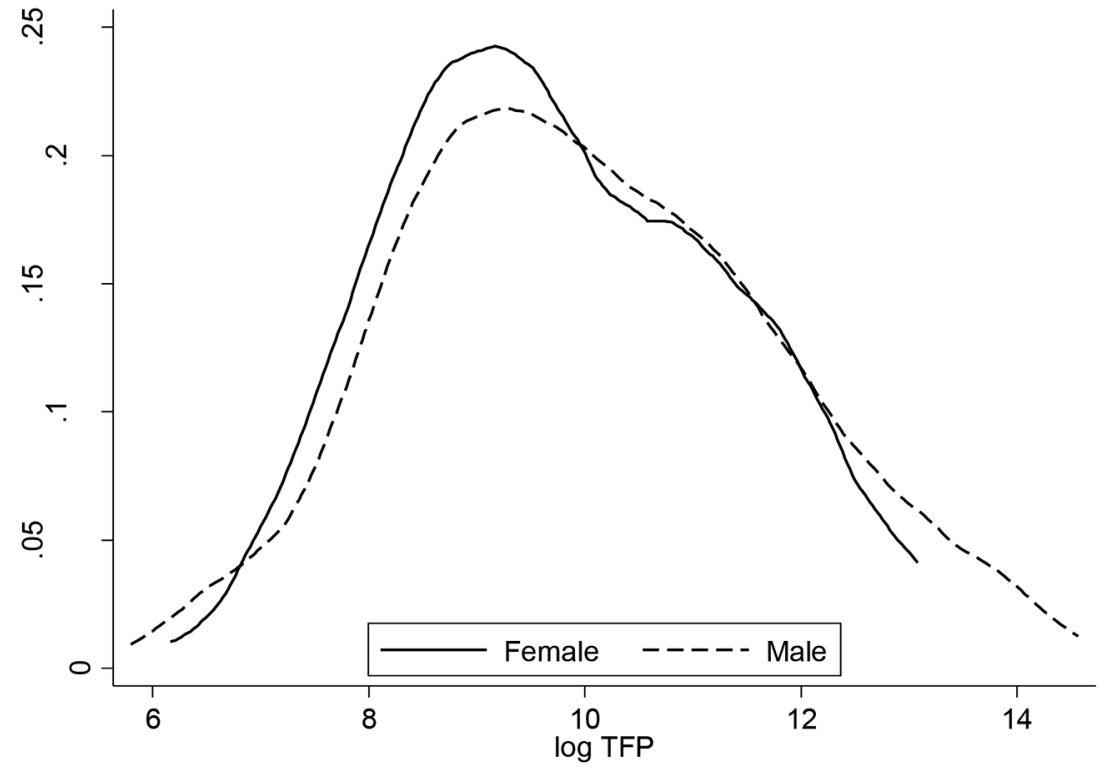

Figure A2. Female- versus male-owned firm productivity distributions, Addis Ababa only. Densities of log total factor productivity (TFP) distributions are estimated using an Epanechnikov kernel function and a bandwidth that minimizes the mean integrated squared error under Gaussian assumptions. Top and bottom $1 \%$ of log TFP distributions are trimmed (separately for male and female distributions). 


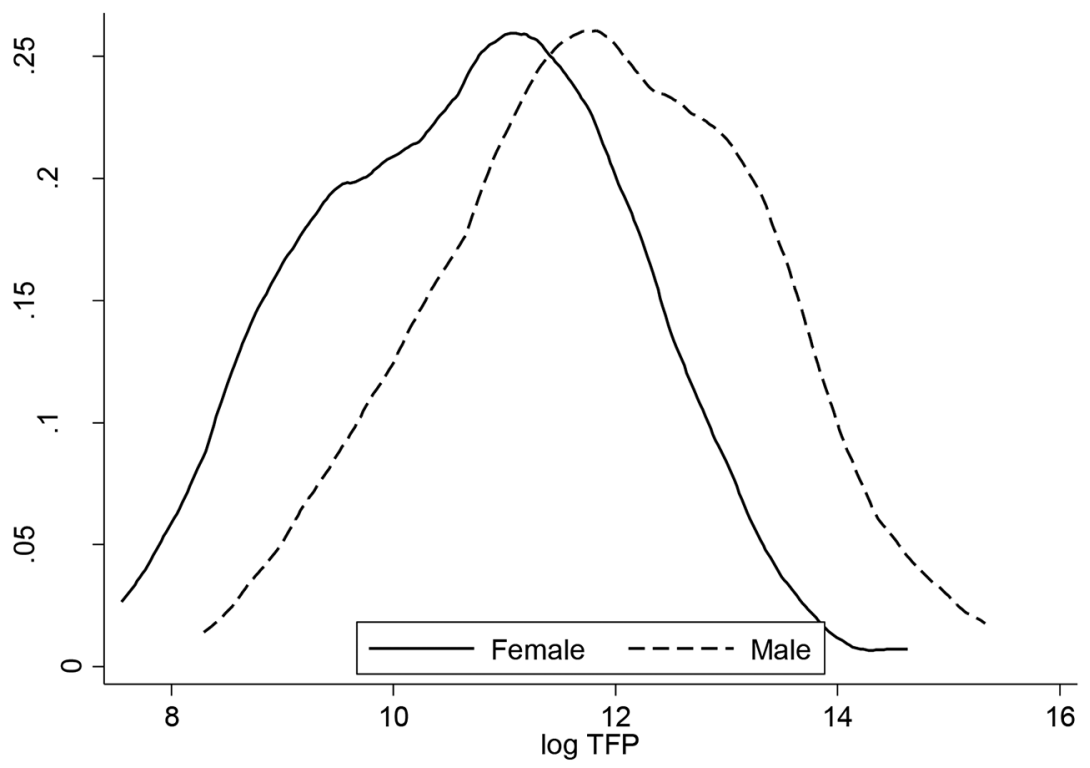

Figure A3. Female- versus male-owned firm productivity distributions, food and beverages industry (International Standard Industrial Classification 15) only. Densities of log total factor productivity (TFP) distributions are estimated using an Epanechnikov kernel function and a bandwidth that minimizes the mean integrated squared error under Gaussian assumptions. Top and bottom 1\% of log TFP distributions are trimmed (separately for male and female distributions).

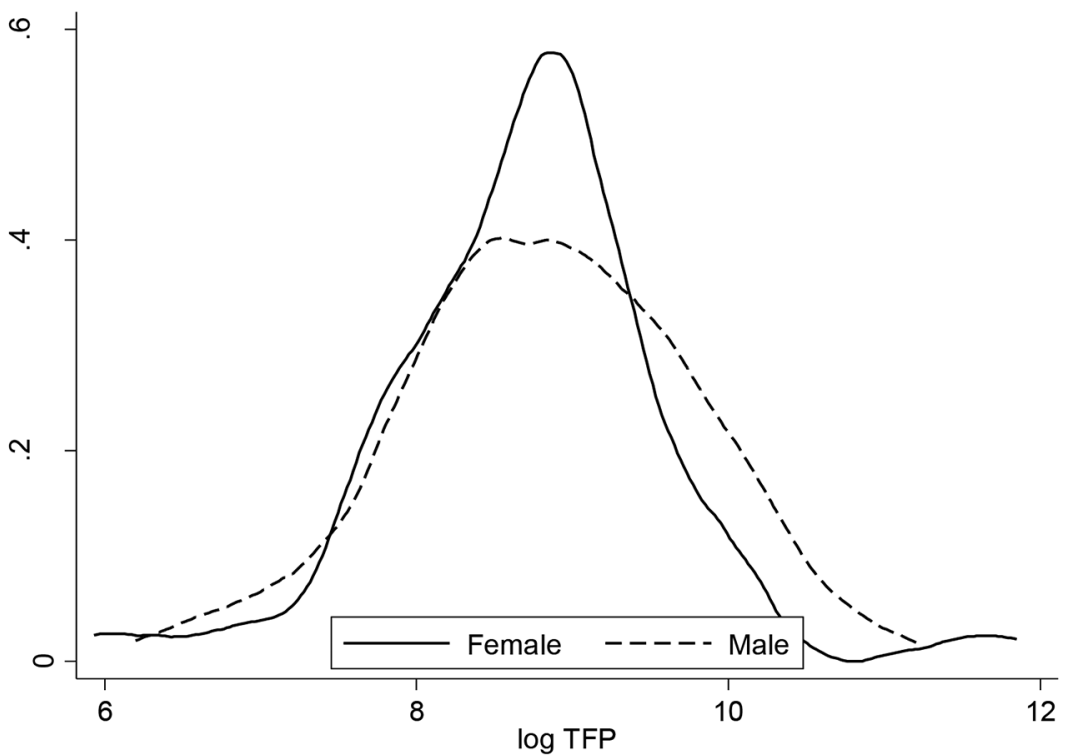

Figure A4. Female- versus male-owned firm productivity distributions, mineral products industry (International Standard Industrial Classification 26) only. Densities of log total factor productivity (TFP) distributions are estimated using an Epanechnikov kernel function and a bandwidth that minimizes the mean integrated squared error under Gaussian assumptions. Top and bottom $1 \%$ of log TFP distributions are trimmed (separately for male and female distributions). 


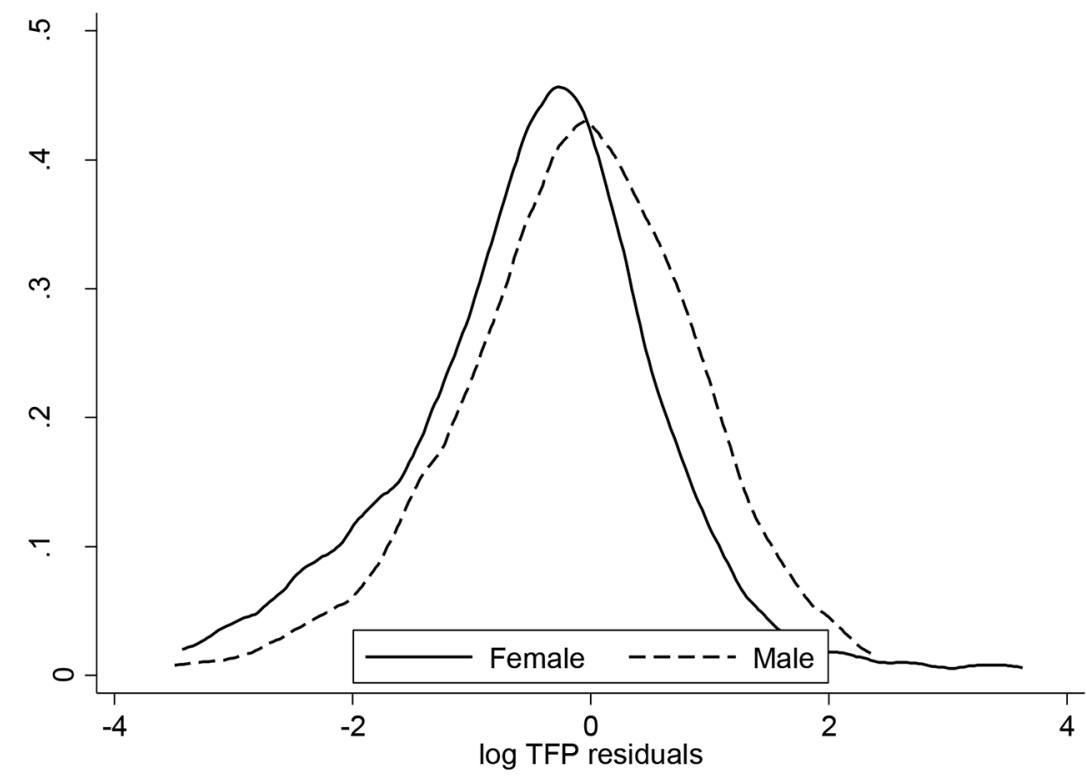

Figure A5. Female- versus male-owned firm productivity residual distributions, controlling for sectors. Residuals are obtained from a regression of log total factor productivity (TFP) on four-digit International Standard Industrial Classification industry dummies. Densities are estimated using an Epanechnikov kernel function and a bandwidth that minimizes the mean integrated squared error under Gaussian assumptions. Top and bottom 1\% of log TFP residual distributions are trimmed (separately for male and female distributions).

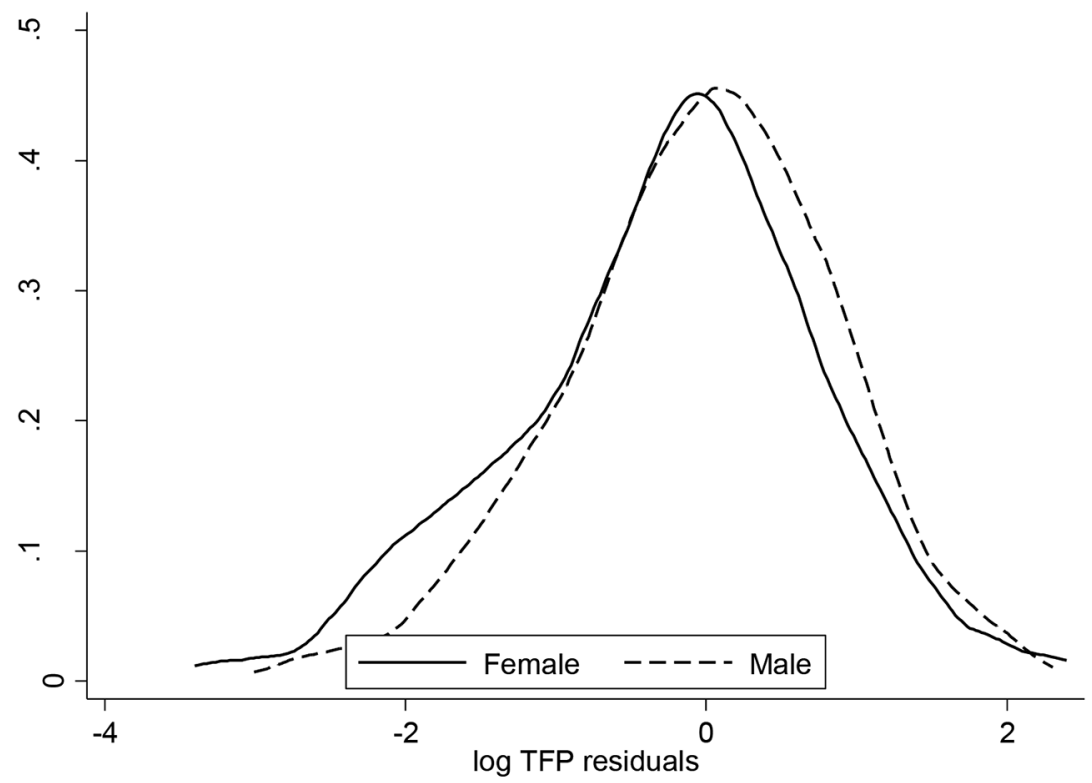

Figure A6. Female- versus male-owned firm productivity residual distributions, controlling for sectors, firm size, and capital intensity. Residuals are obtained from a regression of log total factor productivity (TFP) on four-digit International Standard Industrial Classification industry dummies, log of number of employees, and log of ratio of capital to the number of employees. Densities are estimated using an Epanechnikov kernel function and a bandwidth that minimizes the mean integrated squared error under Gaussian assumptions. Top and bottom 1\% of log TFP residual distributions are trimmed (separately for male and female distributions). 
TABLE A1

CENSUS FIRMS' SHARE OF TOTAL NUMBER OF FIRMS, EMPLOYMENT, AND VALUE ADDED IN 2008 BY INDUSTRY

\begin{tabular}{|c|c|c|c|c|c|c|c|}
\hline \multirow[b]{2}{*}{ Industry } & \multirow[b]{2}{*}{$\begin{array}{c}\text { ISIC } \\
\text { Revision } 3\end{array}$} & \multicolumn{2}{|c|}{ Number of Firms } & \multicolumn{2}{|c|}{ Persons Engaged } & \multicolumn{2}{|c|}{ Value Added } \\
\hline & & Total & $\begin{array}{l}\text { Census } \\
\text { Firms (\%) }\end{array}$ & Total & $\begin{array}{l}\text { Census } \\
\text { Firms (\%) }\end{array}$ & $\begin{array}{l}\text { Total (million } \\
\text { birr) }\end{array}$ & $\begin{array}{l}\text { Census } \\
\text { Firms (\%) }\end{array}$ \\
\hline Food $^{a}$ & 15 & 25,073 & 1.93 & 116,452 & 35.79 & $4,416.09$ & 87.84 \\
\hline Tobacco & 16 & 1 & 100 & 1,254 & 100 & 344.34 & 100 \\
\hline Textiles & 17 & 1,391 & 1.80 & 14,887 & 81.25 & 215.89 & 90.91 \\
\hline Wearing apparel & 18 & 3,136 & 1.24 & 14,225 & 53.67 & 175.28 & 65.44 \\
\hline Leather, footwear & 19 & 129 & 64.34 & 8,817 & 98.11 & 367.92 & 99.60 \\
\hline Wood and cork & 20 & 160 & 43.75 & 3,581 & 90.23 & 57.24 & 94.63 \\
\hline Paper and printing & $21-22$ & 901 & 15.87 & 10,668 & 83.81 & 478.91 & 98.43 \\
\hline Chemicals & 24 & 86 & 93.02 & 7,815 & 99.53 & 531.37 & 99.96 \\
\hline Rubber and plastic & 25 & 82 & 100 & 8,751 & 100 & 446.03 & 100 \\
\hline $\begin{array}{l}\text { Other nonmetallic } \\
\text { mineral }\end{array}$ & 26 & 945 & 51.64 & 20,185 & 87.62 & $1,764.04$ & 96.81 \\
\hline Basic iron and steel & 27 & 15 & 100 & 1,329 & 100 & 280.16 & 100 \\
\hline $\begin{array}{l}\text { Fabricated metal } \\
\text { products }\end{array}$ & 28 & 4,456 & 2.27 & 20,538 & 25.50 & 620.66 & 71.31 \\
\hline $\begin{array}{c}\text { Machinery and } \\
\text { equipment }\end{array}$ & 29 & 4 & 100 & 206 & 100 & 9.35 & 100 \\
\hline Motor vehicles & 34 & 15 & 100 & 1,727 & 100 & 168.45 & 100 \\
\hline $\begin{array}{l}\text { Furniture; } \\
\text { manufacturing }\end{array}$ & & & & & & & \\
\hline NEC & 36 & 8,874 & 3.37 & 42,189 & 17.71 & 440.29 & 36.89 \\
\hline Total & & 45,268 & 4.26 & 272,624 & 49.03 & $10,316.03$ & 88.93 \\
\hline
\end{tabular}

Source. Authors' elaborations on Central Statistical Authority manufacturing census data and Central Statistical Authority (2010).

Note. Industries are here reported at the two-digit level of the International Standard Industrial Classification (ISIC; revision 3). Industries 30 and 31 are not reported by Central Statistical Authority official documents given the very small number of firms covered. NEC $=$ not elsewhere classified.

a Includes grain mills.

TABLE A2

DISTRIBUTION OF FIRMS PER YEAR BY OWNERSHIP

\begin{tabular}{lcc}
\hline Year & Number of Firms & Female Owned (\%) \\
\hline 2003 & 795 & 12.70 \\
2004 & 857 & 13.42 \\
2005 & 715 & 9.79 \\
2006 & 1,007 & 11.92 \\
2007 & 1,206 & 11.86 \\
2008 & 1,577 & 12.43 \\
2009 & 1,792 & 12.22 \\
\hline
\end{tabular}

Source. Authors' elaborations on Central Statistical Authority manufacturing census data.

Note. In 2005 (Ethiopian year 1997), the census was run as a representative survey. Ownership is based on whether female-owned capital is larger than $50 \%$ of the total. 
TABLE A3

DISTRIBUTION OF FIRMS BY REGION AND OWNERSHIP (PERCENT OF TOTAL)

\begin{tabular}{lrrr}
\hline Region & Male Owned & Female Owned & All \\
\hline Tigray & 10.25 & 4.47 & 9.55 \\
Afar & .52 & .42 & .50 \\
Amhara & 9.36 & 9.24 & 9.35 \\
Oromia & 16.94 & 14.75 & 16.67 \\
Somali & .59 & .31 & .55 \\
Benshangul & .23 & .10 & .21 \\
Southern Nations, Nationalities, and Peoples & 11.11 & 5.71 & 10.46 \\
Gambela & .24 & .52 & .28 \\
Harari & 1.26 & 2.18 & 1.37 \\
Addis Ababa & 47.69 & 59.92 & 49.17 \\
Dire Dawa & 1.82 & 2.39 & 1.89 \\
\hline
\end{tabular}

Source. Authors' elaborations on Central Statistical Authority manufacturing census data.

Note. Ownership is based on whether female-owned capital is larger than $50 \%$ of the total.

TABLE A4

DISTRIBUTION OF FIRMS BY INDUSTRY AND OWNERSHIP (PERCENT OF TOTAL)

\begin{tabular}{llrrr}
\hline \multicolumn{1}{c}{ Industry } & $\begin{array}{c}\text { Male } \\
\text { ISIC }\end{array}$ & $\begin{array}{r}\text { Female } \\
\text { Owned }\end{array}$ & Owned & Total \\
\hline 15 & Manufacturing of food products and beverages & 24.41 & 34.85 & 25.68 \\
26 & Manufacturing of other nonmetallic mineral products & 18.91 & 26.24 & 19.80 \\
22 & Publishing, printing, and reproduction of recorded media & 6.18 & 8.51 & 6.47 \\
36 & Manufacturing of furniture; manufacturing NEC & 15.93 & 8.09 & 14.98 \\
20 & Manufacturing of wood and of products of wood and cork, & 2.06 & 3.53 & 2.24 \\
& $\quad$ except furniture & & & \\
25 & Manufacturing of rubber and plastics products & 5.11 & 3.53 & 4.92 \\
19 & Tanning and dressing of leather; manufacturing of luggage, & 5.97 & 3.11 & 5.62 \\
& handbags, saddlery, harness, and footwear & & & \\
28 & Manufacturing of fabricated metal products, except & 6.40 & 3.11 & 6.00 \\
& $\quad$ machinery and equipment & & & \\
24 & Manufacturing of chemicals and chemical products & 5.21 & 2.70 & 4.91 \\
17 & Manufacturing of textiles & 2.93 & 2.28 & 2.86 \\
18 & Manufacturing of wearing apparel; dressing and dyeing & 2.69 & 1.45 & 2.54 \\
29 & Manufacturing of machinery and equipment NEC & .46 & 1.14 & .54 \\
21 & Manufacturing of paper and paper products & 1.06 & 1.04 & 1.06 \\
27 & Manufacturing of basic metals & 1.17 & .21 & 1.06 \\
34 & Manufacturing of motor vehicles, trailers, and semitrailers & 1.26 & .21 & 1.13 \\
16 & Manufacturing of tobacco products & .10 & .00 & .09 \\
30 & Manufacturing of office, accounting, and computing machinery & .01 & .00 & .01 \\
31 & Manufacturing of electrical machinery and apparatus & .11 & .00 & .11 \\
\hline
\end{tabular}

Source. Authors' elaborations on Central Statistical Authority manufacturing census data.

Note. Industries are here reported at the two-digit level of the International Standard Industrial Classification (ISIC; revision 3) but are originally at the four-digit level in the data. Ownership is based on whether female-owned capital is larger than $50 \%$ of the total. NEC $=$ not elsewhere classified. 
TABLE A5

RESULTS OF PROBIT REGRESSIONS FOR FIRM EXIT

\begin{tabular}{|c|c|c|c|c|}
\hline Variable & $\begin{array}{l}\text { Exit } \\
(1)\end{array}$ & $\begin{array}{l}\text { Exit (excluding 2005) } \\
\text { (2) }\end{array}$ & $\begin{array}{l}\text { Exit } \\
\text { (3) }\end{array}$ & $\begin{array}{c}\text { Exit (excluding 2005) } \\
\text { (4) }\end{array}$ \\
\hline Female & $\begin{array}{l}.0582 \\
(.0570)\end{array}$ & $\begin{array}{l}.0785 \\
(.0600)\end{array}$ & $\begin{array}{l}.0698 \\
(.0658)\end{array}$ & $\begin{array}{c}.0873 \\
(.0705)\end{array}$ \\
\hline Total factor productivity & & & $\begin{array}{l}-.0449^{\star \star} \\
(.0191)\end{array}$ & $\begin{array}{r}-.0384^{\star} \\
(.0212)\end{array}$ \\
\hline Age & & & $\begin{array}{l}-.401 * \star \star \\
(.0548)\end{array}$ & $\begin{array}{l}-.407^{\star \star \star} \\
(.0596)\end{array}$ \\
\hline Employees & & & $\begin{array}{c}-.147^{\star \star \star} \\
(.0250)\end{array}$ & $\begin{array}{l}-.143^{\star \star \star} \\
(.0269)\end{array}$ \\
\hline Capital intensity & & & $\begin{array}{l}-.0319^{\star \star \star} \\
(.0108)\end{array}$ & $\begin{array}{l}-.0364^{\star \star \star} \\
(.0120)\end{array}$ \\
\hline Exporter & & & $\begin{array}{l}.0277 \\
(.167)\end{array}$ & $\begin{array}{c}-.0333 \\
(.179)\end{array}$ \\
\hline Importer & & & $\begin{array}{r}-.0342 \\
(.0581)\end{array}$ & $\begin{array}{r}-.0342 \\
(.0616)\end{array}$ \\
\hline Constant & $\begin{array}{c}-1.237^{\star \star \star} \\
(.0213)\end{array}$ & $\begin{array}{c}-1.255^{\star \star \star} \\
(.0225)\end{array}$ & $\begin{array}{l}.902 \\
(.550)\end{array}$ & $\begin{array}{l}-2.885^{\star \star \star} \\
(.322)\end{array}$ \\
\hline Observations & 7,949 & 7,234 & 5,730 & 5,034 \\
\hline Industry fixed effects & No & No & Yes & Yes \\
\hline Region fixed effects & No & No & Yes & Yes \\
\hline Year fixed effects & No & No & Yes & Yes \\
\hline
\end{tabular}

Note. Standard errors are clustered at the firm level. The dependent variable is a dummy variable taking the value of 1 if the firm leaves the sample and 0 otherwise. The samples of the estimations in cols. 2 and 4 exclude 2005, since in that year a representative survey was run instead of the full census.

$\star p<.10$.

$\star * \quad p<.05$.

$\star \star \star ~ p<.01$. 


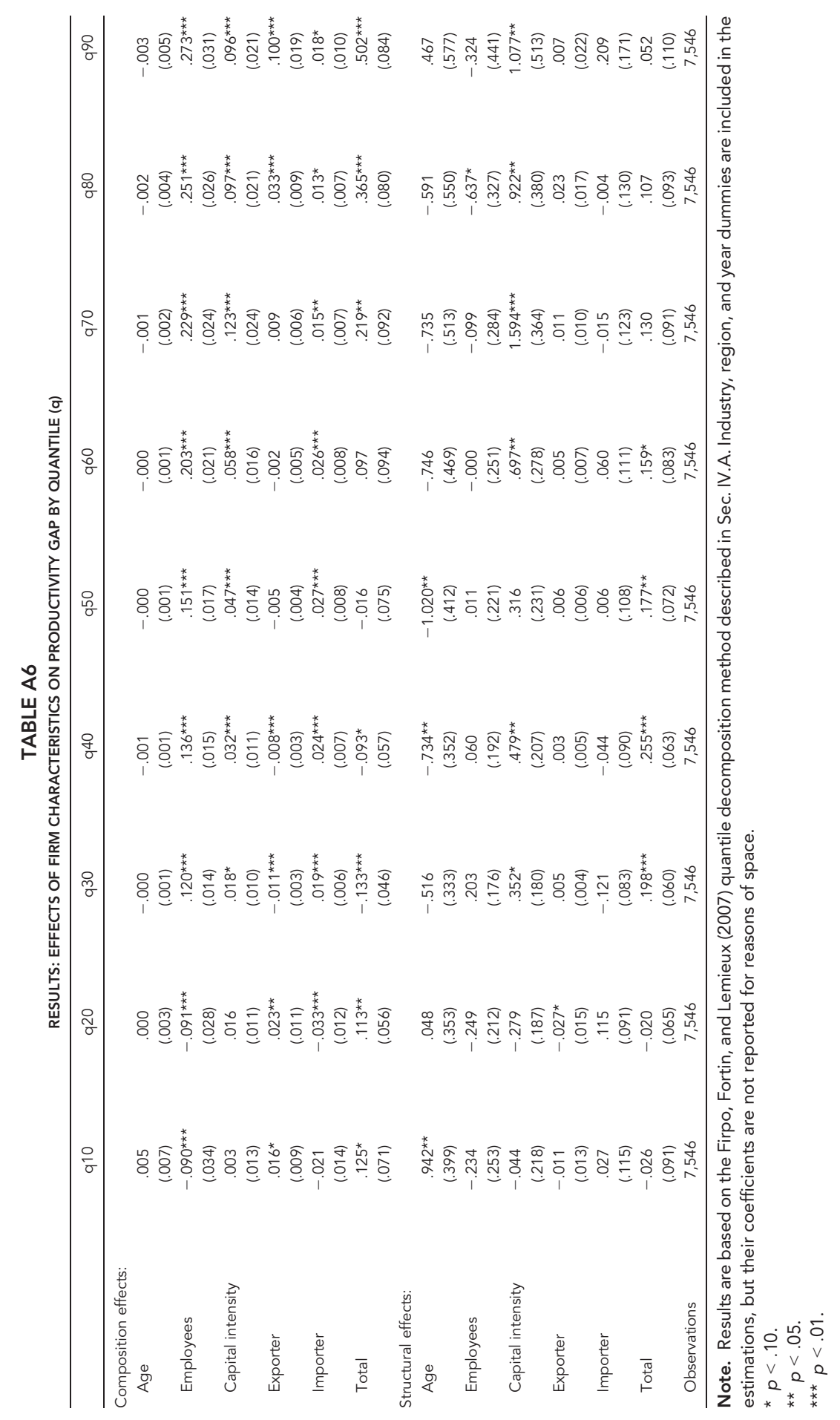


TABLE A7

AVERAGE CHARACTERISTICS OF FIRMS AT BOTTOM/TOP OF PRODUCTIVITY DISTRIBUTION

\begin{tabular}{|c|c|c|c|c|c|c|}
\hline & \multicolumn{3}{|c|}{ Bottom $10 \%$} & \multicolumn{3}{|c|}{ Top $10 \%$} \\
\hline & $\begin{array}{l}\text { Female } \\
\text { Owned }\end{array}$ & $\begin{array}{l}\text { Male } \\
\text { Owned }\end{array}$ & $\begin{array}{c}\text { Female/ } \\
\text { Male }\end{array}$ & $\begin{array}{l}\text { Female } \\
\text { Owned }\end{array}$ & $\begin{array}{c}\text { Male } \\
\text { Owned }\end{array}$ & $\begin{array}{c}\text { Female/ } \\
\text { Male }\end{array}$ \\
\hline Number of employees & 19.2 & 28.5 & .68 & 102.0 & 318.4 & .32 \\
\hline Female/male workers & 1.1 & .5 & 2.23 & .4 & .5 & .70 \\
\hline Skilled workers & .7 & .4 & 1.61 & .6 & .4 & 1.39 \\
\hline Unskilled workers & 1.2 & .6 & 2.01 & .3 & .8 & .40 \\
\hline Wage per worker (birr) & $2,937.9$ & $4,249.8$ & .69 & $10,367.8$ & $9,955.9$ & 1.04 \\
\hline Access to credit (yes/no) & .2 & .2 & .91 & .5 & .5 & .90 \\
\hline Fixed assets to employees (birr) & $29,505.7$ & $29,601.6$ & 1.00 & $96,320.8$ & $111,581.4$ & .86 \\
\hline Exporter (yes/no) & .0 & .0 & .. & .1 & .3 & .30 \\
\hline Importer (yes/no) & .5 & 6 & .79 & .6 & .6 & .97 \\
\hline Sales (birr) & $509,578.3$ & $886,987.2$ & .57 & $18,900,000$ & $48,600,000$ & .39 \\
\hline Value added (birr) & $442,123.5$ & $658,005.3$ & .672 & $20,300,000$ & $48,400,000$ & .42 \\
\hline \multicolumn{7}{|l|}{ Largest three industries } \\
\hline (percent of total firms) & 57.1 & 69.4 & .82 & 67.8 & 49.0 & 1.38 \\
\hline Based in Addis (\%) & 36.5 & 59.7 & .61 & 28.8 & 38.0 & .76 \\
\hline Observations & 77 & 696 & .11 & 59 & 714 & .08 \\
\hline
\end{tabular}

Source. Authors' elaborations on Central Statistical Authority manufacturing census data.

\section{References}

Alibhai, S., N. Buehren, S. Papineni, and R. Pierotti. 2017. "Crossovers- Female Entrepreneurs Who Enter Male Sectors: Evidence from Ethiopia.” Policy Research Working Paper no. 8065, World Bank, Washington, DC.

Aterido, R., and M. Hallward-Driemeier. 2011. "Whose Business Is It Anyway? Closing the Gender Gap in Entrepreneurship in Sub-Saharan Africa." Small Business Economics 37, no. 4:443-64.

Bardasi, E., C. M. Blackden, and J. C. Guzman. 2007. "Gender, Entrepreneurship, and Competitiveness in Africa." In Africa Competitiveness Report, ed. World Bank and African Development Bank, 69-85. Geneva: World Economic Forum.

Bardasi, E., S. Sabarwal, and K. Terrell. 2011. "How Do Female Entrepreneurs Perform? Evidence from Three Developing Regions." Small Business Economics 37, no. 4:417-41.

Bernhardt, A., E. Field, R. Pande, and N. Rigol. 2017. "Household Matters: Revisiting the Returns to Capital among Female Micro-Entrepreneurs." NBER Working Paper no. 23358, National Bureau of Economic Research, Cambridge, MA.

Bigsten, A., and M. Gebreeyesus. 2007. "The Small, the Young, and the Productive: Determinants of Manufacturing Firm Growth in Ethiopia." Economic Development and Cultural Change 55, no. 4:813-40.

. 2009. "Firm Productivity and Exports: Evidence from Ethiopian Manufacturing." Journal of Development Studies 45, no. 10:1594-614.

Bruhn, M. 2009. "Female-Owned Firms in Latin America: Characteristics, Performance, and Obstacles to Growth." Policy Research Working Paper no. 5122, World Bank, Washington, DC. 
Campos, F., and M. Gassier. 2017. "Gender and Enterprise Development in SubSaharan Africa: A Review of Constraints and Effective Interventions." Policy Research Working Paper no. 8239, World Bank, Washington, DC.

Central Statistical Authority. 2009. "Report on Large and Medium Scale Manufacturing and Electricity Industry Survey." Addis Ababa: Central Statistical Agency.

- 2010. "Report on Small Scale Manufacturing Industries Survey." Addis Ababa: Central Statistical Agency.

Combes, P.-P., G. Duranton, L. Gobillon, D. Puga, and S. Roux. 2012. “The Productivity Advantages of Large Cities: Distinguishing Agglomeration from Firm Selection.” Econometrica 80, no. 6:2543-94.

Del Gatto, M., A. Di Liberto, and C. Petraglia. 2011. "Measuring Productivity." Journal of Economic Surveys 25, no. 5:952-1008.

de Mel, S., D. McKenzie, and C. Woodruff. 2008. "Returns to Capital in Microenterprises: Evidence from a Field Experiment." Quarterly Journal of Economics 123, no. 4:1329-72.

- 2009. "Are Women More Credit Constrained? Experimental Evidence on Gender and Microenterprise Returns." American Economic Journal: Applied Economics 1 , no. 3:1-32.

Egger, M., G. D. Smith, M. Schneider, and C. Minder. 1997. "Bias in Meta-Analysis Detected by a Simple, Graphical Test.” BMJ 315:629-34.

Fafchamps, M., D. McKenzie, S. R. Quinn, and C. Woodruff. 2014. "Microenterprise Growth and the Flypaper Effect: Evidence from a Randomized Experiment in Ghana." Journal of Development Economics 106:211-16.

Fiorini, M., M. Sanfilippo, and A. Sundaram. 2018. "Input Tariffs, Roads and Firm Performance: Evidence from Ethiopia.” IGC Working Paper no. F-32403-ETH-1, International Growth Center, London.

Firpo, S., N. Fortin, and T. Lemieux. 2007. "Decomposing Wage Distributions Using Recentered Influence Function Regressions.” Working paper, University of British Columbia.

73.

Flabbi, L., M. Macis, A. Moro, and F. Schivardi. 2016. "Do Female Executives Make a Difference? The Impact of Female Leadership on Gender Gaps and Firm Performance.” NBER Working Paper no. 22877, National Bureau of Economic Research, Cambridge, MA.

Hallward-Driemeier, M. 2011. Enterprising Women: Expanding Economic Opportunities in Africa. Washington, DC: World Bank.

Hallward-Driemeier, M., and O. Gajigo. 2015. "Strengthening Economic Rights and Women's Occupational Choice: The Impact of Reforming Ethiopia's Family Law." World Development 70:260-73.

Hardy, M., and G. Kagy. 2018a. "It's Getting Crowded in Here: Experimental Evidence of Demand-Side Constraints in the Gender Profit Gap." Unpublished manuscript.

_. 2018b. "Mind the (Profit) Gap: Why Are Female Enterprise Owners Earning Less than Men?" AEA Papers and Proceedings 108:252-55. 
Hellerstein, J. K., and D. Neumark. 1999. "Sex, Wages, and Productivity: An Empirical Analysis of Israeli Firm-Level Data.” International Economic Review 40, no. 1:95123.

Helpman, E., M. J. Melitz, and S. R. Yeaple. 2004. "Export versus FDI with Heterogeneous Firms.” American Economic Review 94, no. 1:300-16.

Hsieh, C. T., and P. J. Klenow. 2009. "Misallocation and Manufacturing TFP in China and India." Quarterly Journal of Economics 124, no. 4:1403-48.

International Labor Organization. 2015. Women in Business and Management: Gaining Momentum. Geneva: International Labor Organization.

Jones, P. 2012. "Identifying the Effects of Female Ownership on Firm Performance: Evidence from Ghana." Paper presented at the 2012 Centre for the Study of African Economies Conference, University of Oxford, March 18-20.

Juhn, C., G. Ujhelyi, and C. Villegas-Sanchez. 2014. "Men, Women, and Machines: How Trade Impacts Gender Inequality.” Journal of Development Economics 106:179_ 93.

Klapper, L. F., and S. C. Parker. 2011. "Gender and the Business Environment for New Firm Creation.” World Bank Research Observer 26, no. 2:237-57.

Kondo, K. 2016. "Testing for Agglomeration Economies and Firm Selection in Spatial Productivity Differences: The Case of Japan.” RIETI Discussion Paper no. 16E-098, Research Institute of Economy, Trade, and Industry, Tokyo.

. 2017. "Quantile Approach for Distinguishing Agglomeration from Firm Selection in Stata." RIETI Technical Paper no. 17-E-001, Research Institute of Economy, Trade, and Industry, Tokyo.

Kucera, D., and S. Tejani. 2014. "Feminization, Defeminization, and Structural Change in Manufacturing." World Development 64:569-82.

Kumar, N., and A. R. Quisumbing. 2015. "Policy Reform toward Gender Equality in Ethiopia: Little by Little the Egg Begins to Walk." World Development 67:406-23.

Marques, H. 2015. "Does the Gender of Top Managers and Owners Matter for Firm Exports?” Feminist Economics 21, no. 4:89-117.

Melitz, M. J. 2003. "The Impact of Trade on Intraindustry Reallocations and Aggregate Industry Productivity." Econometrica 71, no. 6:1695-725.

Menon, N., and Y. Rodgers. 2009. "International Trade and the Gender Wage Gap: New Evidence from India's Manufacturing Sector." World Development 37, no. 6:965-81.

Niederle, M., and L. Vesterlund. 2007. "Do Women Shy Away from Competition? Do Men Compete Too Much?” Quarterly Journal of Economics 122, no. 3:1067101.

Nix, E., E. Gamberoni, and R. Heath. 2016. "Bridging the Gender Gap: Identifying What Is Holding Self-Employed Women Back in Ghana, Rwanda, Tanzania, and the Republic of Congo." World Bank Economic Review 30, no. 3:501-21.

Nordman, C. J., and J. Vaillant. 2014. "Inputs, Gender Roles or Sharing Norms? Assessing the Gender Performance Gap among Informal Entrepreneurs in Madagascar." IZA Discussion Paper no. 8046, Institute of Labor Economics, Bonn.

Olley, G. S., and A. Pakes. 1996. "The Dynamics of Productivity in the Telecommunications Equipment Industry.” Econometrica 64, no. 6:1263-97. 
Presbitero, A. F., R. Rabellotti, and C. Piras. 2014. "Barking Up the Wrong Tree? Measuring Gender Gaps in Firm's Access to Finance." Journal of Development Studies 50, no. 10:1430-44.

Rijkers, B., and R. Costa. 2012. "Gender and Rural Non-Farm Entrepreneurship." World Development 40, no. 12:2411-26.

Rijkers, B., M. Söderbom, and J. L. Loening. 2010. "A Rural-Urban Comparison of Manufacturing Enterprise Performance in Ethiopia." World Development 38, no. 9:1278-96.

Sabarwal, S., and K. Terrell. 2008. "Does Gender Matter for Firm Performance? Evidence from Eastern Europe and Central Asia." IZA Discussion Paper no. 3758, Institute of Labor Economics, Bonn.

Sanfilippo, M., and A. Seric. 2016. "Spillovers from Agglomerations and FDI. A Multilevel Analysis on SSA Domestic Firms." Review of World Economics 152, no. 1:14776.

Sekkat, K., A. Szafarz, and I. Tojerow. 2015. "Women at the Top in Developing Countries: Evidence from Firm-Level Data." IZA Discussion Paper no. 9537, Institute of Labor Economics, Bonn.

Shiferaw, A. 2009. "Survival of Private Sector Manufacturing Establishments in Africa: The Role of Productivity and Ownership." World Development 37, no. 3:572-84.

2016. "Constraints to Private Investment in a High-Growth Environment: Firm-Level Evidence from Ethiopia.” Working Paper no. 168, Department of Economics, College of William and Mary.

Shiferaw, A., and A. S. Bedi. 2013. "The Dynamics of Job Creation and Job Destruction in an African Economy: Evidence from Ethiopia." Journal of African Economies 22, no. 5:651-92.

Shiferaw, A., M. Söderbom, E. Siba, and G. Alemu. 2015. "Road Infrastructure and Enterprise Dynamics in Ethiopia." Journal of Development Studies 51, no. 11:1541-58.

Siba, E. 2015. "Returns to Physical Capital in Ethiopia: Comparative Analysis of Formal and Informal Firms." World Development 68:215-29.

Siba, E., M. Söderbom, A. Bigsten, and M. Gebreeyesus. 2012. "Enterprise Agglomeration, Output Prices, and Physical Productivity: Firm-Level Evidence from Ethiopia.” Working Paper no. 2012/85, United Nations University-World Institute for Development Economics Research, Helsinki.

Söderbom, M. 2012. "Firm Size and Structural Change: A Case Study of Ethiopia." Journal of African Economies 21, suppl. 2: ii126-ii151.

Van Beveren, I. 2012. "Total Factor Productivity Estimation: A Practical Review." Journal of Economic Surveys 26, no. 1:98-128.

World Bank. 2012. "Gender Differences in Employment and Why They Matter." In World Development Report 2012, ed. World Bank, 198-253. Washington, DC: World Bank.

- 2015. Fourth Ethiopia Economic Update: Overcoming Constraints in the Manufacturing Sector. Washington, DC: World Bank.

World Economic Forum. 2017. The Global Gender Gap Report 2017. Geneva: World Economic Forum. 